\title{
Differences in drone and worker physiology in honeybees (Apis mellifera) ${ }^{1}$
}

\author{
Norbert HRASSNIGG*, Karl CRAILSHEIM \\ Karl-Franzens-Universität Graz, Universitätsplatz 2, A8010 Graz, Austria
}

Received 22 December 2004 - revised 19 January 2005 - accepted 20 January 2005

Published online 1 June 2005

\begin{abstract}
Drones and workers have completely different roles in a honeybee colony. This is reflected in many physiological, morphological and behavioural differences. Our overview mainly focuses on aspects of diet and metabolism in larvae and adults, and on the physiology of digestion. As larvae, drones have different protein and sugar requirements than workers, and in each life stage drones and workers differ in body composition (percentages of glycogen, lipids and proteins). Like queens, drones as adults are nourished by worker-prepared food, and compared to workers their ability to digest is reduced. Mature drones fly usually only under optimal weather conditions. Their flight metabolism and resting metabolism also differ from those of workers. We discuss these differences as adaptations to the different functions of the two sexes within the colony as a superorganism.
\end{abstract}

nutrition / digestion / enzymes / energy metabolism / body reserves

\section{INTRODUCTION}

With respect to physiology, honeybee drones have not been investigated as intensely as workers. This is not so astonishing as drones are not of direct commercial interest and are reared and found in the honeybee colonies only during restricted periods of time - in temperate regions only during part of the summer season (Allen, 1958; Free and Williams 1975; Morse et al., 1967; see also Seeley, 1985; Winston, 1987). When colonies prepare for the winter period they expel drones, often as early as July or August in temperate regions. Therefore, compared to workers, their presence and availability for experiments is restricted to shorter periods.

The quite limited function of drones is to produce sperm and to mate with a queen. A mated queen stores the sperm throughout her life in the spermatheca and keeps it viable there, long after the drone has passed away (Klenk et al., 2004; Phiancharoen et al., 2004). To mate, a drone must find an airborne queen at a drone congregation area and then compete with hundreds of other drones (Gary, 1963; Ruttner and Ruttner, 1972; Page, 1986; Koeniger, 1988; Berg et al., 1997). Accordingly, drones exhibit anatomical and physiological adaptations for strong and forceful flying (Radloff et al., 2003), and they possess elaborate mating organs (Woyke and Ruttner, 1958; Koeniger, 1986; Koeniger et al., 1991; Koeniger and Koeniger, 1991, 2000) and powerful sense organs, such as big eyes with a high number of omatids and long antennae with many sensilla for visual and olfactory orientation towards airborne queens (Seidl, 1980). Also, drones lack hypopharyngeal glands (= brood food glands), wax glands, and most of the structures to collect food. Thus, although the drone's head is bigger than a worker's head, its "tongue" is shorter, its

* Corresponding author: norbert.hrassnigg@uni-graz.at

${ }^{1}$ Manuscript editor: Gudrun Koeniger 
mandibles are smaller, the mandibular glands are very small, and the honey stomach is slenderer. Furthermore, their hind legs lack the pollen collection devices present in workers (Snodgrass, 1956; Lensky et al., 1985).

In contrast to drones, workers perform an enormous variety of tasks. They clean the hive, tend the brood, nourish the workers, drones and queen, work for nest homeostasis (Schmickl and Crailsheim, 2002, 2004), produce wax, forage for and process food, and communicate the location and profitability of the food sources to their nest mates (reviewed by Seeley, 1985, 1995; Winston, 1987; Robinson, 1992; Calderone, 1998). Usually, workers proceed from withinnest tasks to outside tasks with age (age-polyethism) (Seeley, 1982). For this variety of duties they are equipped with well developed hypopharyngeal and mandibular glands, wax glands and scent glands. Workers have to work economically to produce wax, to build cells, and to store a surplus of carbohydrates as honey in the combs so that the colony is able to survive dearth periods during the warm season as well as the cold winter period.

There are differences between drones and workers in morphology, physiology and behaviour. Here we give an overview mainly about physiology, focusing on some aspects of metabolism in larvae and adults, and on the physiology of digestion and energy metabolism. We discuss whether the differences between drones and workers are adaptations to the different roles and functions of the two sexes. The data we cite usually refer to honeybees of European origin, and if not stated otherwise they are given as mean \pm standard deviation.

\section{DEVELOPMENT AND NUTRITION OF WORKER AND DRONE LARVAE}

Honeybee workers are raised from fertilised eggs, whereas normal drones are produced from unfertilised eggs. Both types of eggs vary in size over the season and between colonies (Henderson, 1991). Drone eggs were found to be longer and wider than worker eggs (Reinhardt, 1960). But size differences are quite small, which might be the reason that Henderson (1991) did not find a significant difference between male and female eggs. Worker eggs develop slightly more rapidly than drone eggs at the same temperature (Harbo and Bolten, 1981), so that female larvae hatched in the study of Harbo and Bolten at $34.8{ }^{\circ} \mathrm{C}$ after $71.4 \pm 1.2 \mathrm{~h}$ (mean $\pm \mathrm{sd}$ ) and male larvae about $3 \mathrm{~h}$ later. The respiration rate of these two kinds of eggs is temperature dependent, but between male and female eggs there was no difference found in the amount of consumed oxygen (Mackasmiel and Fell, 2000).

The investment of nurses to raise an individual drone larva far exceeds that for a worker larva (Haydak, 1970). This is reflected in the increased tending of drone larvae (Calderone and Kuenen, 2003), and it obviously can be deduced from the weight gain of larvae during the larval period (Tab. I). For worker larvae it has been shown that in the first larval instars the increase in weight has a genetic component, with one strain developing faster than another (Sutter et al., 1968), but this has not yet been investigated in drones. Worker larvae reach a maximum fresh weight, measured at the time of cell sealing, of 144-162 mg, and drone larvae reach 262-419 mg (reviewed by Jay, 1963; see also Strauss 1911; Nelson et al., 1924; Stabe, 1930; Bishop, 1961; Wang, 1965; Thrasyvoulou and Benton, 1982). Thus drone larvae attain 1.8-2.6 times the weight of worker larvae. Similar differences in weight can also be seen in the freshly emerged adults, after a 24-day developmental time (egg to the adult) in drones and a 21-day period in workers (Tab. I). The weight of freshly emerged drones of European honeybees was found to be 277-290 mg if they were not infested by Varroa destructor mites, which exert a significant influence on weight at emergence (Schneider and Drescher, 1987; Duay et al., 2003). The weight of workers of European honeybees emerging from their cells was measured as $116.37 \pm 0.61 \mathrm{mg}$ (Bowen-Walker and Gunn, 2001) or $123.3 \mathrm{mg}$ (SchattonGadelmayer and Engels, 1988). But it has to be pointed out that the deviations depending on nutritional and environmental factors can be considerable (Levin and Haydak, 1951; De Groot, 1953; Gontarski, 1953; Kunert and Crailsheim, 1988).

Drones may considerably deviate in size. When haploid larvae are raised in worker cells, which are smaller than drone cells, the resulting adult males are called "dwarf" drones because of their unusually small size. Such drones produce fewer total spermatozoa than large 
Table I. Developmental time and weights of worker and drone larvae, and estimated amounts of nutrients needed to raise one individual; (a) estimated portion of protein derived from jelly feeding, (b) estimated portion of protein derived from pollen fed directly to the larvae, (c) calculated total pollen-need of nurses to raise one larva (sum of estimated $95 \%$ for jelly production and $5 \%$ fed directly to larva); the protein content of pollen was assumed to be $20 \%$;

$?=$ data are not well documented; references are given in the text.

\begin{tabular}{lcc}
\hline & Worker & Drone \\
\hline Developmental time from oviposition of egg - emergence of adult (Days) & $\sim 21$ & $\sim 24$ \\
Mean fresh weight of eggs (mg) & $0.03-0.1$ & $\sim 0.1$ \\
Maximum larval fresh weight (mg) & $\sim 144-162$ & $\sim 262-419$ \\
Mean fresh weight at emergence (mg) & $\sim 120$ & $\sim 277-290$ \\
& & \\
Total amount of carbohydrates (mg) & $\sim 59.4$ & $\sim 98.2$ \\
Total amount of proteins (mg) & $25-37.5$ & $65-97.5$ \\
(a) Protein from jelly (\%) & $\sim 95$ & $\sim 95 ?$ \\
(b) Protein from directly fed pollen (\%) & $\sim 5$ & $\sim 5 ?$ \\
(c) Total pollen-need to raise one larva (mg) & $125-187.5$ & $325-487.5$ \\
\hline
\end{tabular}

drones. But calculated on a weight basis, per gram body mass small drones produce $20 \%$ more spermatozoa than large drones (Schlüns et al., 2003). If we assume the amount of food needed to gain one gram final body mass to be similar in both types of drones, workers should favourably raise small drones to produce more spermatozoa per deployed gram of food (Schlüns et al., 2003). But since the workers raise drones in worker cells only under specific circumstances, the more costly rearing of large drones must be advantageous in some other aspects. It might be that the bigger sperm volume of a large drone disproportionately increases its representation in a queen's offspring. Although the difference was not very big, such an increase was shown in artificially inseminated queens by Schlüns et al. (2004). Another aspect could be the conversion of nutrients into body mass, which does not necessarily have to be identical in drones raised in large drone cells or small worker cells. So, it is possible that per gram body mass the investment into a large drone is less than into a small one, but this still has to be demonstrated. A larger size might also be advantageous if it increases the ability to compete for queens during mating flights (see last chapter). As the cell size is controlled by the workers and not by the drones themselves, colony level selection should favour a drone size that is optimal for fitness at the colony level, which has been discussed by Kraus et al. (2004).

The nutritional requirements for normal workers and drones are as follows. The total amount of carbohydrates (sugars) to raise a worker has been estimated to be roughly $59.4 \mathrm{mg}$, and $98.2 \mathrm{mg}$ for a drone (Rortais et al., 2005) (Tab. I). However, exact measurements are not yet available. From feeding experiments it was calculated that, depending on the diet, 4-6 mg of nitrogen is needed to raise one worker larva (reviewed by Haydak, 1970). This would yield 25-37.5 mg of protein (conversion factor of $\mathrm{N}$ in protein $=6.25$ ). This amount of protein is present in about $125-187.5 \mathrm{mg}$ pollen with an estimated protein content of $20 \%$ (Tab. I). We can only speculate about the amount of protein (pollen) needed to raise one drone. The nitrogen content of drone pupae was found to be higher than that of a worker by a factor of about 2.6 (recalculated from data given by Straus, 1911), which corresponds well to the higher weight reached by drone larvae. So, if we assume a similar degree of utilization of the food given to drone larvae, the amount needed to raise one larva would be $65-97.5 \mathrm{mg}$ protein, derived from $325-487.5 \mathrm{mg}$ pollen (Tab. I).

The bulk of the proteins fed to worker and drone larvae originate from the nurse workers' 
glandular secretions (jelly), especially from the hypopharyngeal glands (Brouwers, 1982; Knecht and Kaatz, 1990), but some also from mandibular and postcephalic glands (Lensky and Rakover, 1983). Only a minor fraction is derived from direct pollen feeding. The amount of pollen fed directly to worker larvae was recently determined by Babendreier et al. (2004). Studying larvae raised in small hives containing about 1000 workers, they found that worker larvae were fed over their entire developmental time with a total of only 1.52-2.04 mg of pollen, which provides less than $5 \%$ of the total protein requirement needed for larval development (Tab. I). The authors also discuss the amount of pollen fed to "dwarf" larvae that were much lighter in weight than normal drone larvae. They were only $39 \%$ heavier than the worker larvae and had consumed only $36 \%$ more pollen, which means that on a unit weight basis the total amount of fed pollen is similar. But since the authors analysed only a few "dwarf drone larvae", these results still have to be validated. Also Simpson (1955) found relatively low pollen consumption in worker larvae. He estimated that less than one-tenth of the nitrogen requirements of growing worker larvae are obtained from the pollen in their food and concluded that direct pollen feeding is not necessary for normal development.

As already mentioned, drone larvae are also fed with pollen, but the amount in the first 3 days of larval life is negligible and as small as in workers (Matsuka et al., 1973). The food given young drone larvae, 1-3 days of age, is milky-white in appearance, and that for older larvae is dirty yellow-brown, presumably due to the addition of honey and pollen. The food for older larvae contains less protein and fat, but more carbohydrates, than the food for younger larvae (Haydak, 1957a, 1970). During early development, the food supplied to drone larvae seems very similar to the food for worker larvae in protein and carbohydrate content. However, while worker jelly is modified after a larval age of $84 \mathrm{~h}$, drone jelly is modified after $108 \mathrm{~h}$ (Brouwers, 1984; Brouwers et al., 1987). That might be related to the fact that larval development of drones is delayed compared to that of workers (Stabe, 1930). Rhein (1951) considered the difference between worker and drone jelly to be of little relevance, since he was able to raise one drone larva to adulthood and others to the pupal stage with worker food which he had taken from cells with larvae of similar age as the drone larvae.

\section{BODY COMPOSITION AND METABOLISM IN WORKER AND DRONE LARVAE AND PUPAE}

In contrast to the small amounts of lipids and glycogen as reserve substances found in the adult worker bees (see next section), worker larvae contain quite high amounts of those reserves at some developmental stages (Tab. II). The larval and pupal fat body differentiates with age and stores high amounts of protein, fat, and glycogen (Fyg, 1965; Marx et al., 1987; Krajewska and Hryniewiecka-Szyfter, 1988). At larval maturity the fat body constitutes at least three-fourths of the total tissue mass excluding blood (Bishop, 1961). Most glycogen is found at the late larval stage $(\sim 6 \mathrm{~d})$ and at the nymph and white-eyed pupal stages $(\sim 7-$ 9 d) (Straus, 1911; Melampy and Olsan, 1940; Czoppelt and Rembold, 1970). Czoppelt and Rembold (1970) found that glycogen makes up $4.5-5.0 \%$ of total body weight in the nymph and white-eyed pupa. Assuming in these stages a water content of $77 \%$, the portion of glycogen of the dry substance would be 19.6-21.7\% . Recalculating data of Melampy and Olsan (1940) yields a value of $28.3 \%$ of dry weight, a similar value as given by Straus (1911). In the course of development, this high amount of reserve carbohydrate decreases steadily until the imaginal stage, as shown by all the abovecited authors (Tab. II).

The absolute amounts of lipids increase in both worker and drone larva as they increase in weight in the course of larval development, and the amounts decrease during metamorphosis (Straus, 1911; Melampy et al., 1940; Cantrill et al., 1981). But relative amounts evolve differently (Tab. II). The highest relative amount of lipids is found in the 3-day-old worker larva. The amount decreases up to the nymph stage $(\sim 7 \mathrm{~d})$, increases in pupae with white and dark eyes ( 9-11 d), and then decreases until emergence of the adult worker (Czoppelt and Rembold, 1970; Cantrill et al., 1981). The portion of lipids in $3 \mathrm{~d}$ old larvae, calculated from the data of these authors, would be $36.5 \%$ of dry weight, when assuming a water content of the 


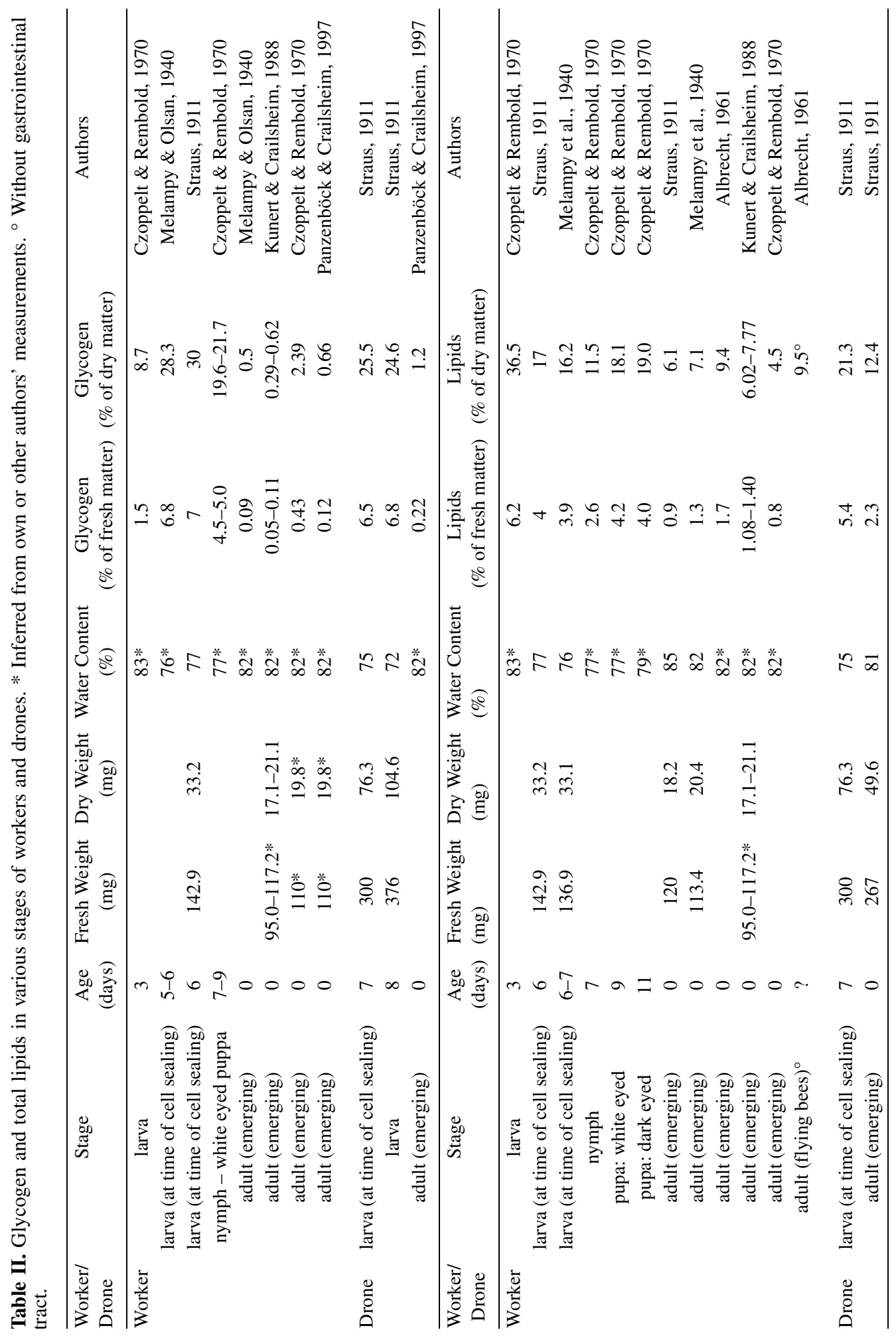


tissue of $83 \%$ for these larvae (water content of such larvae was taken from own unpublished measurements). The highest absolute amount of lipids $(5.37 \mathrm{mg}$ ) was found in 6-7 d old larvae with a fresh weight of $136.89 \mathrm{mg}$ (Melampy et al., 1940). This is $3.9 \%$ of fresh weight or $16.2 \%$ of dry weight, at a water content of $76 \%$ (Tab. II). In the worker larvae the absolute and relative amount of lipids decrease until emergence of the imago, but after the nymph stage another maximum of the relative amount is reached before it finally decreases (Czoppelt and Rembold, 1970). The formation of this maximum is considered to be fuelled by glycogen. The free lipids - except free fatty acid found in the workers' hemolymph reach maximum concentrations during nymphosis and decrease thereafter (Bounias et al., 1985).

Data on the chemical composition of drone larvae are scarce, but some can be obtained from Straus (1911). The pattern of glycogen accumulation in drone larvae is similar to the pattern in worker larvae (Tab. II). Straus found the highest absolute amount around the time when the cell was sealed, at the late larval stage, with $6.5 \%$ of fresh weight or $25.5 \%$ of dry weight in drones, compared to $7 \%$ and $30 \%$, respectively, in workers. As in the worker larvae the absolute and relative glycogen content decrease towards the imaginal stage.

According to Straus (1911), drone larvae accumulate (in absolute and relative numbers) more lipids than worker larvae (Tab. II). Around the time of sealing the cell he found lipids at amounts of $5.4 \%$ of fresh weight $(21.3 \%$ of dry weight), while worker larvae had $4 \%$ of fresh weight ( $17 \%$ of dry weight), which is in accordance with the data given by Melampy et al. (1940). We suppose this overall trend observed for drone larvae to be sound, but the number of analysed individuals was small and their age was not determined with precision.

The protein content of larvae has either been inferred from determinations of their nitrogen content (Straus, 1911; Melampy et al., 1940; Imdorf et al., 1998), or has been determined directly (Hepburn et al., 1979; Kunert and Crailsheim, 1987) (see Tab. III). There is a general increase in the absolute amount of protein as larvae grow. But the relative amount of protein, as percentage of body weight, decreases with increasing fresh weight (Kunert and
Crailsheim, 1987). In worker and drone larvae a maximum of the absolute amount of protein is reached at the time the cell is sealed. Thereafter, until emergence the absolute amount remains at a relatively constant level (Straus, 1911; Melampy et al., 1940). But the relative amount of protein in the larva or pupa (dry weight) varies to some extent, which mainly depends on the increase and decrease of the reserve substrates, glycogen and lipid (Tabs. II, III). The maximum amount of protein is present in $6-7 \mathrm{~d}$ old worker larvae, which is $\sim 13.1 \mathrm{mg}$ (i.e. $~ 9.5 \%$ of fresh matter and $\sim 39.5 \%$ of dry matter, at $136.89 \mathrm{mg}$ weight and $76 \%$ water content ), and in $7 \mathrm{~d}$ old drone larvae it is $\sim 34.4 \mathrm{mg}$ (i.e. $\sim 10.3 \%$ of fresh matter and $\sim 40.3 \%$ of dry matter, at $300 \mathrm{mg}$ weight and $75 \%$ water content). The data were recalculated from Melampy et al. (1940) and from Straus (1911) using a conversion factor of 6.25 to determine the protein content from nitrogen $(\mathrm{N}[\mathrm{mg}] \times 6.25=$ protein $[\mathrm{mg}])$.

The protein concentration in hemolymph depends on the stage of the pupa. It seems that there are only small differences between workers and drones (Weinberg and Madel, 1985). For worker bees it was shown that there exist specific patterns of hemolymph proteins for larvae and for adults, as well as patterns common to both stages (Lensky, 1971).

In worker and also drone larvae the high mass of glycogen and lipids may exceed half of their dry weight. Besides providing molecules for building the imaginal organs during metamorphosis, they also supply energy for this process, which can be deduced from the decreasing caloric values in the course of metamorphosis (Melampy et al., 1940). As an indication of the substances utilised in metabolism, the respiratory quotient $(\mathrm{RQ})$ is determined (Harrison and Suarez, 2004). It is the ratio of carbon dioxide production to oxygen consumption. Melampy and Willis (1939) found the RQ in worker larvae to exceed unity - in the range between 1.13 and $1.42-$ which is the case when carbohydrates are used to build up fat reserves. Later on, in the pupal stage, the RQ decreases to values smaller than 1.0. The authors give a mean value of 0.96 , indicating the metabolizing of not only glycogen but also fat. Hepburn et al. (1979) give RQ values for sealed brood stages of African workers to be $0.6-0.8$. This is conclusive in the light of the decrease of fat and 


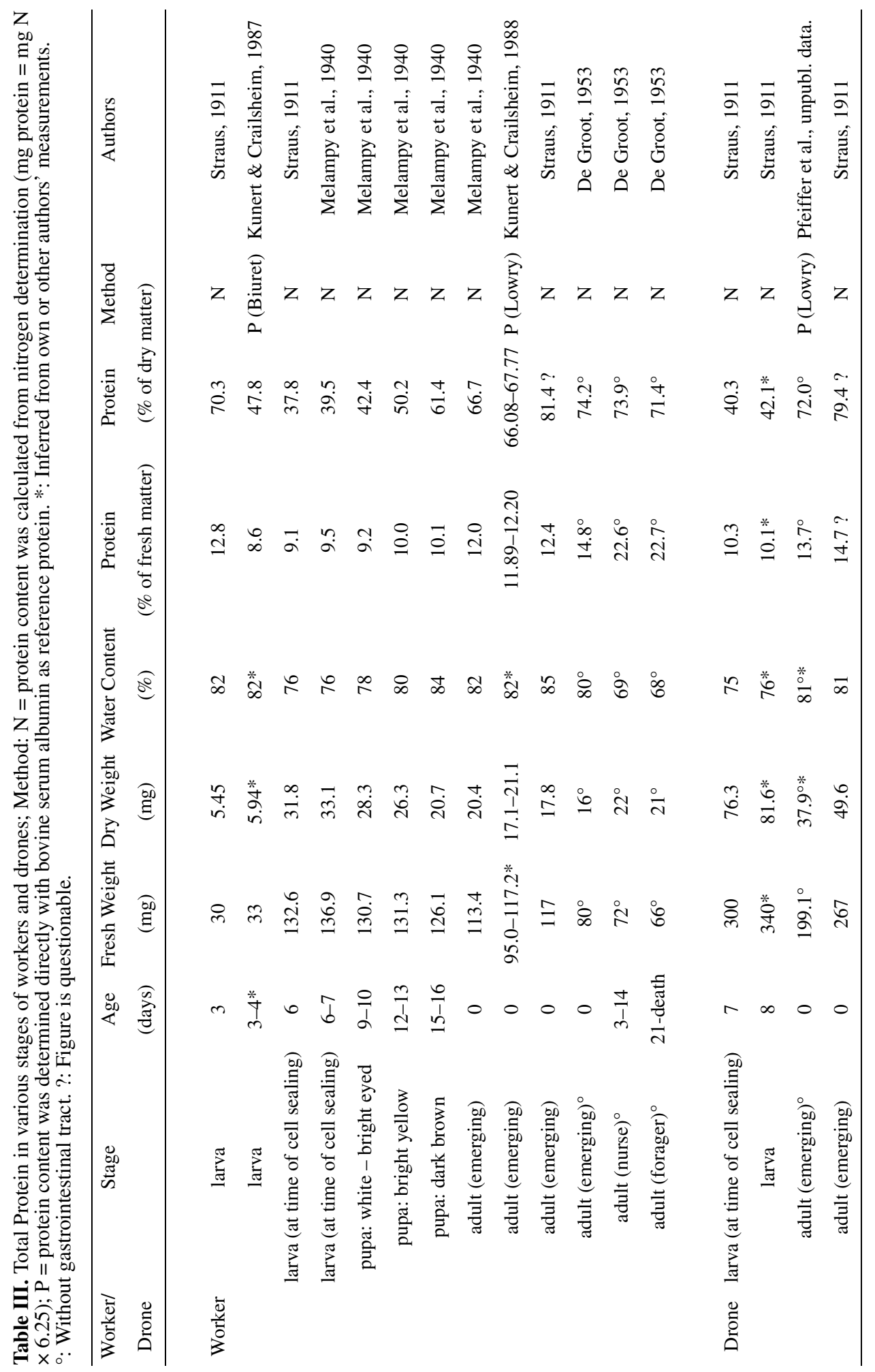


glycogen reserves in pupae (Straus, 1911; Czoppelt and Rembold, 1970; Hepburn et al., 1979; Cantrill et al., 1981). While Melampy and Willis (1939) also give data about queens, no such information on the RQ of drone larvae are available.

Allen (1959) measured the oxygen consumption in worker and drone larvae. It increases rapidly in the period after hatching, followed by a period with a lower rate of increase. Calculated on a unit weight basis, the oxygen consumption decreases in worker and drone larvae between hatching of the larvae and sealing of the cells, which agrees with the findings for workers and queens (Melampy and Willis, 1939), and also with measurements of carbon dioxide production in workers (Petz et al., 2004). In addition, Allen found that drone larvae clearly consume more oxygen than worker larvae at the same weight, which she interpreted to be caused by a relatively higher growth rate of drone larvae. She concluded this from comparing weight data for drones (Straus, 1911) and for workers (Melampy and Willis, 1939). But this comparison does not appear to be very reliable, as Straus determined larval age quite imprecisely, only within approximately \pm 12 hours. Additionally, Allen's conclusions are not supported by the weight measurements performed by Stabe (1930), who compared worker, drone and queen larvae much more accurately, and who showed in drone larvae a lower growth rate at young larval ages. We conclude that it is difficult and highly speculative to interpret the higher uptake of oxygen by drone larvae, until new measurements on drone larval development, oxygen consumption and carbon dioxide production are performed.

\section{BODY COMPOSITION AND METABOLISM IN ADULT WORKERS AND DRONES}

In contrast to the high amounts of glycogen and lipids present at various larval stages, emerging adult workers do not have sufficient reserves of these substances to survive longer periods without feeding (Tab. II). Czoppelt and Rembold (1970) found the lipids in the whole tissue of freshly emerged individuals to make up less than $1 \%$ of fresh weight (recalculated from data given by the authors). This corre- sponds well with the value of $0.93 \%$ of fresh weight, or $6.14 \%$ of dry weight, given by Straus (1911), and is also in accordance with the amount of 1.03-1.7 mg per newly emerged bee found in African and European honeybee workers (Hepburn et al., 1979; Cantrill et al., 1981; Kunert and Crailsheim, 1988).

Also glycogen is found in quite small amounts in freshly emerged adults of both genders (Tab. II) (Melampy and Olsan, 1940; Czoppelt and Rembold, 1970; Kunert and Crailsheim, 1988; Panzenböck and Crailsheim, 1997). The data are in the range of $0.05-0.47 \mathrm{mg}$ per worker, which is $0.05-0.43 \%$ of fresh weight, at an assumed body weight of $110 \mathrm{mg}$. Data vary according to the method used; therefore, comparisons should be made with caution. Panzenböck and Crailsheim (1997), who compared drones and workers in parallel, found in freshly emerged drones relatively more glycogen than in same-aged workers (drones: 0.55$0.59 \mathrm{mg}$, i.e. $0.22 \%$ of fresh weight; workers: $0.13 \mathrm{mg}$, i.e. $0.12 \%$ of fresh weight) (Tab. II).

The amount of reserve carbohydrate seems to be age dependent. While in drones a higher relative amount was found in young $(0-1 \mathrm{~d})$ than in older individuals (3-18 d), in workers the amount was smaller in younger than in $28 \mathrm{~d}$ old animals (for a comparison of data see Panzenböck and Crailsheim, 1997). However, among other age groups the authors did not find significant differences. Also, other authors determined lower levels of thorax and abdominal glycogen in young compared to old (= foraging-age) workers (Neukirch, 1982; Harrison, 1986; Leta et al., 1996). Therefore, glycogen is considered to be involved in flight metabolism as one source of energy. But it was calculated that the total glycogen stores would enable foragers a flight distance of only $335 \mathrm{~m}$, and drones of $230 \mathrm{~m}$ (Panzenböck and Crailsheim, 1997), which shows its relatively low importance for flight compared to other, low-molecular carbohydrates (i.e. sugars). It is interesting to note that also for male bumble bees (Bombus terrestris L.) sugar is the main source of energy, and the amounts of lipids and glycogen are negligible (Surholt et al., 1988).

Estimates of the protein content of adult bees are often based on the nitrogen content (Haydak, 1934, 1937a, b, 1959; Lotmar, 1939; De Groot, 1953) (Tab. III). De Groot analysed several thousand samples of freshly emerged workers 


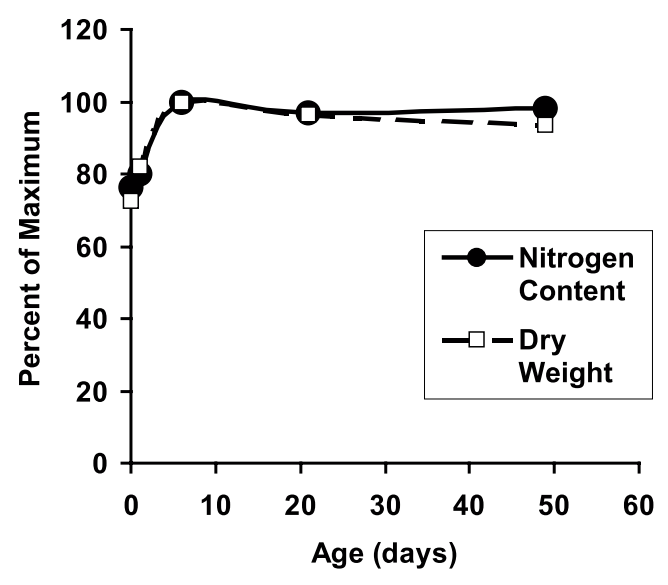

Figure 1. Depicted is the initial increase of body dry weight and nitrogen content of worker bees without gastrointestine, and the light decrease in older animals. The maximum values were reached in 6-day old bees and were taken as $100 \%$ (nitrogen content $=2.45 \mathrm{mg}$, dry weight $=20.7 \mathrm{mg}$ ); redrawn after Haydak (1959).

without the alimentary tract and found the nitrogen content to range from 1.49 to $2.33 \mathrm{mg}$ per bee, with an average of $1.9 \mathrm{mg}$. In nurseaged bees (3-14 d) which were properly supplied with proteins, the dry weight $(22 \mathrm{mg})$ and the nitrogen content $(2.6 \mathrm{mg})$ were found to increase by $\sim 37 \%$ from age 0d to nurse-aged bees, which indicates massive growth in these adult bees. In foragers, dry weight and nitrogen content slightly decreased to $21 \mathrm{mg}$ and $2.4 \mathrm{mg}$, respectively. If we apply the conversion factor (6.25) to calculate the amount of protein from nitrogen, it is clear that proteins account for most of the dry weight (71-74\%) in these animals, and account for most of the growth phenomena after emergence (Tab. III). Haydak (1959) found the nitrogen content to increase in the head, thorax and abdomen without the gastrointestine, from freshly emerged to 6 day-old workers, by about $31 \%$ (see Fig. 1). He found the highest increase in the head (38\%) (percentages were recalculated), which especially reflects the development of hypopharyngeal glands in these nurse-aged bees (see below). Finally, the decrease of protein in older workers is driven by a reduction in the head and abdomen, but not the thorax, where the highest nitrogen content was found in old foraging-age bees, which usually perform extensive flights. In another study, in which the emerging bees showed lower contents of nitrogen, the increase was even higher (Haydak, 1934). In accordance with this development, Haydak (1957b) found the abdominal fat body to increase from emergence to the nursing age and to decrease later in old workers (see also Maurizio, 1954). In drones the abdominal fat body seems to be present only in animals up to 2 days old, and here it is only presented by a few aggregations of cells (Haydak, 1957b). However, fat cells have also been described in the head (Snodgrass, 1956), but we have no information about age related changes. The described growth of workers is associated with pollen consumption (De Groot, 1950; Haydak, 1970), and with trophallactic protein transfer from other worker bees (Naiem et al., 1999).

Although drones eat very small amounts of pollen (Szolderits and Crailsheim, 1993), they increased their body protein content - without the intestinal tract - by about $47 \%$ within the 9 days following emergence, when they were kept normally in a colony together with worker bees (Pfeiffer et al., unpublished data). A similar increase in the nitrogen content was found by De Groot (1953), based on whole-body analysis, and was also described by Haydak (1959), who gives data only for heads and thoraces. An increase in the protein content between $5 \mathrm{~d}$ and $12 \mathrm{~d}$ old drones was also described by Berger et al. (1997). The increase involves an accumulation in the thorax, where most of the flight muscles are located, and also in the abdomen with its sexual organs, but not in the head (Crailsheim et al., 1997). We consider this to reflect the final formation of the sexual organs, and flight muscle maturation, in the presence of nurses. It was shown that isolated drones, feeding on pollen without nursing workers, do not fully develop their mucus glands (Mindt, 1962), while in normally kept drones mucus protein content increases steeply during the first 5 days of life (Colonello and Hartfelder, 2003). This is also supported by results of Pfeiffer et al. (unpublished data), and underlines the importance of jelly-feeding workers to drones. It seems that results presented by Jaycox (1961), who assessed maturity by determining the number of spermatozoa, contrast with these findings. Jaycox found an influence of temperature on the number of spermatozoa, but no 
influence of food, whether drones were kept with pure syrup or syrup mixed with pollen, or jelly, or whether drones were kept with or without nurses. However, he only determined sperm number, but did not investigate other parameters, like sperm viability or mucus gland development, which have been shown to be affected by the kind of food ingested (Mindt, 1962). In A. mellifera drones the mucus is pressed into the endophallus to enable a strong connection between drone and queen during the mating process (Koeniger and Koeniger, 1991). As discussed by Colonello and Hartfelder (2003) mucus gland proteins seem to play an additional role in the stimulation of oogenesis / oviposition (see also Colonello and Hartfelder, 2005), as might other bioactive mucus gland factors or a mechanical stimulatory effect of the everted endophallus in the queen's bursa copulatrix (Koeniger, 1976, 1981). While A. mellifera invests in high amounts of mucus proteins and high numbers of spermatozoa (10-12 million), another Apis species, A. florea, produces little mucus and smaller numbers of spermatozoa ( 0.44 million). This is achieved by a different fixation of drone and queen during copulation the metatarsal organs fix drone and queen - and by a more direct sperm transfer into the queen's spermatheca (Koeniger et al., 1989; Koeniger and Koeniger, 1991).

Survival of adult workers is negatively correlated with nursing intensity and flight activity (Merz et al., 1979; Neukirch, 1982) and positively with fat-body stores (Maurizio, 1954, Fluri and Bogdanov, 1982). Changes in behaviour and in body stores enhance the life span of workers and enable them to survive the winter period (Mattila et al., 2001). A colony prepares for winter by producing workers that are better nourished at emergence (Kunert and Crailsheim, 1988), and by workers eating pollen over a longer period (Moritz and Crailsheim, 1987). Life span is also variable in drones. It is short in summer and prolonged in autumn, which seems to be caused by a decreased flight activity (Fukuda and Ohtani, 1977). But workers in colonies with a queen often recognise and expel drones in autumn (Morse et al., 1967; Free and Williams, 1975), so they don't reach their potential life expectancy, even if they would actively prepare for winter by accumulating additional body reserves. But that has not been investigated so far. Drones are recognised by workers probably by their odours (Wakonigg et al., 2000; Moritz and Neumann, 2004).

\section{CHARACTERISTICS OF WORKER AND DRONE HEMOLYMPH}

The inner organs of bees float in the hemolymph, which roughly corresponds functionally to the blood in vertebrates: it contains proteins, amino acids, sugars and many other substances in relatively high concentrations (Wyatt, 1961, 1967). But insect hemolymph is not as finely regulated in its composition as the blood of vertebrates. Into the hemolymph hormones are released, one of which, juvenile hormone $(\mathrm{JH})$ is produced by the corpora allata. The corpora allata are smaller in adult drones than in workers or queens (van Laere, 1971). The function of $\mathrm{JH}$ is to specifically modulate development and behaviour (Rembold, 1987; Hartfelder, 1990; Robinson, 1992, 2002; Fahrbach, 1997).

Hartfelder et al. (1993) showed that the developmental profiles of corpora allata activity are quite similar in late larval stages of drones and workers, but very different from the profile in queens. In drone pupae no juvenile hormone synthesis was detected by Tozetto et al. (1995), but they found that after eclosion $\mathrm{JH}$ synthesis increases to a maximum in $9 \mathrm{~d}$ old drones and decreases thereafter (see also Rembold, 1987). Experimental application of JH III promoted the flight activity of drones (Tozetto et al., 1997), as did the JH analog methopren (Giray and Robinson, 1996). In workers high $\mathrm{JH}$ titres are associated with foraging (Huang et al., 1991; Jassim et al., 2000; Elekonich et al., 2001). This shows that JH hormone promotes flight activity in workers as well as in drones. It might well be that in drones $\mathrm{JH}$ also exerts functions in the spermatogenesis or mucus production by the accessory glands, as was discussed by Tozetto et al. (1997).

Age-related changes in the protein content of the hemolymph occur in workers as well as in drones (Sinitzky and Lewtschenko, 1971; Trenczek et al., 1989; Cremonez et al., 1998). In drones it increases rapidly within the first days after emergence, reaching a peak at the 3 rd day and decreasing after the first week. The hemolymph titre of vitellogenin roughly follows this 
pattern (Trenczek et al., 1989). Vitellogenin is produced by females as a specific precursor yolk protein, but might also have some other yet unknown function, as drones and unfertile workers also express this protein, and it is found in their hemolymph (Engels et al., 1990). It is incorporated as vitellin into the eggs during the vitellogenic growth phase of the oocyte. As vitellogenin represents in drones only a minor fraction of the hemolymph proteins (Trenczek and Engels, 1986), it was not detected in drones in earlier investigations (Engels, 1974; Engels and Fahrenhorst, 1974; Rutz and Lüscher, 1974). This could have been caused by the analyses of only just emerged drones or quite old drones, since vitellogenin synthesis falls to zero in old drones (Trenczek et al., 1989).

Although the absolute amount of vitellogenin in drones is much lower than in workers, the overall ontogenetic patterns of its synthesis and hemolymph titre are very similar in both (Engels and Fahrenhorst, 1974; Trenczek et al., 1989). Piulachs et al. (2003) found vitellogenin-mRNA in drones only after the freshly molted adult stage, while they found it in workers in the late pupal stage. In workers vitellogenin seems to be a source for the proteinaceous royal jelly (Adam et al., 2003), but this does not explain its appearance in drones. The function of vitellogenin in drones is discussed in the context of the transport of sugars, lipids, phosphates, vitamins and hormones (Piulachs et al., 2003), but its role remains to be proved. Some hemolymph proteins are also found in the drones' reproductive organs (Lensky and Kalinsky, 1971), but to our knowledge this was not stated for vitellogenin. Hemolymph protein patterns in adult drones have also been investigated in the context of Varroa parasitation (Glinski and Jarosz, 1984).

The concentration of free amino acids in the hemolymph of workers and drones depends significantly on age (Crailsheim and Leonhard, 1997; Leonhard and Crailsheim, 1999). In both workers and drones the highest concentrations of free amino acids occur at 5 days of age and decrease in older individuals. The maximum concentrations found in drones are over three times as high as in workers, $90.5 \pm 10.98 \mathrm{nmol} / \mu \mathrm{L}$ and $25.32 \pm 7.42 \mathrm{nmol} / \mu \mathrm{L}$ respectively, and rather match those of queens (Hrassnigg et al., 2003a). In all three castes the predominant amino acid was found to be proline, in workers at concentrations of $50-80 \%$ of all free amino acids, and in drones at concentrations of 3152\% (Crailsheim and Leonhard, 1997; Leonhard and Crailsheim, 1999). Proline is not an essential amino acid required in the honeybees diet (de Groot, 1953), as it can be synthesised from glucose (cf. Lehninger et al., 2001). Proline is used in oxidative metabolism of drones at a higher rate than either phenylalanine or leucine (Berger et al., 1997). It was found that the amount of proline in worker hemolymph is reduced after flight (Crailsheim and Leonhard, 1997; Micheu et al., 2000), which was also measured in thorax homogenates by Barker and Lehner (1972). From this the authors calculated that proline fuels only a small portion of flight metabolism in workers, providing only $0.1 \%$ of flight energy. These authors also found a depletion of proline in the thoraces of flown drones. Tsacopoulos et al. (1994) proposed proline as a second substrate for the Krebs cycle through the making of glutamate and, in turn, alphaketoglutarate, in the neurons of the honeybee retina. In their experiments light stimulation caused a clear decrease of proline in the drone retina. Despite these and other data on amino acids in the honeybee, the ultimate functions of proline in the bees' energy metabolism have not yet been elucidated.

Honeybees gain most of their energy from sugars and not from other substrates (Beenakkers, 1969; Sacktor 1970). Beutler (1937) determined the average sugar concentration in the hemolymph of workers to be $2 \%$ and in drones $1.2 \%$. She, like others, found large variation in the sugar concentration in workers (Beutler, 1937; Maurizio, 1965; Bounias, 1981; Abou-Seif et al., 1993; Woodring et al., 1993; Leta et al., 1996; Bozic and Woodring, 1997; Blatt and Roces, 2001, 2002). In drones the variation in sugar concentration was small, but Beutler analysed only a few drones taken from a single colony, and a more extensive investigation would be of interest. Maurizio (1965) found the sugar spectrum in drones to be similar to that in workers. In the worker and drone hemolymph the same sugars were detected: glucose, fructose, trehalose and sucrose (Alumot et al., 1969). However, in workers sucrose is apparently not always present (Arslan et al., 1986; Woodring et al., 1993), or is found at low concentrations only (Abou-Seif et al., 1993). 


\section{PHYSIOLOGY OF DIGESTION IN WORKERS AND DRONES}

Workers have to ingest enough food - nectar, pollen and jelly - to provide themselves with sufficient nutrients. They digest much of the pollen to produce proteinaceous secretions in their hypopharyngeal glands (Crailsheim et al., 1992). These secretions are fed as brood food to the larvae in their cells, but also to other workers, to the queen and to drones (Crailsheim, 1991, 1992). For this reason the workers in a normal colony eat much more pollen than they would need to support only their own metabolism. In workers this feeding on pollen depends strongly on age and function. The nurse-aged bees consume the highest pollen quantities, while freshly emerged workers and the oldest workers consume least (Morton, 1951; Crailsheim et al., 1992; Hrassnigg and Crailsheim, 1998a). In parallel with pollen uptake runs the workers' ability to digest proteins (Rinderknecht et al., 1968; Moritz and Crailsheim, 1987), and fat (Loidl and Crailsheim, 2001).

Drones eat less pollen than workers do. The maximum amount found in their entire gastrointestinal tract is only about $2-3 \%$ of the amount found as a maximum in workers. Drones consume pollen only during the first few days after adult emergence, while workers do so over a longer period (Szolderits and Crailsheim, 1993) and are better equipped for the filtering of pollen from their crop as they posses a larger proventriculus than drones (Pabst and Crailsheim, 1990). Workers consume more pollen when brood has to be nursed (Hrassnigg and Crailsheim, 1998a). While many aspects of worker behaviour depend on colony conditions, there is no information about such a relationship in drones. We do not know, for example, if a drone's pollen consumption is affected by the amount of brood present in the colony. However, unlike workers, drones don't have to produce jelly proteins from the ingested pollen to feed larvae, so we expect the direct impact of brood to be rather small. An indirect impact is likely, if the willingness of workers to provide drones with proteinaceous food depends on the amount of unsealed brood. As workers provide drones with more proteinaceous secretions, the drones' hunger for pollen and consequently their pollen uptake should decrease.
It seems that drones have a lower honey stomach capacity than workers (Snodgrass, 1956). Hoffmann (1966) found that drones which had sugar solution provided ad libitum had a maximum uptake of $90 \mu \mathrm{L}$, but most often only 30 $35 \mu \mathrm{L}$, and the honey stomach of 40 drones flying out from the colony had a mean weight of only $18 \mathrm{mg}$, which corresponds to the data given by Burgett (1973) $(17.7 \pm 9.1 \mathrm{mg})$ and Mindt (1962) (30 mg). Free (1957) found in drones leaving the hive a mean of $20 \mathrm{mg}$, and in drones returning to it a mean crop weight of $2.5 \mathrm{mg}$, and in drones inside the colony $3.6 \mathrm{mg}$. Coelho (1996) calculated for a drone leaving the hive with crop contents of $16.1 \mathrm{mg}$ a theoretical flight time of $\sim 37 \mathrm{~min}$, which is a little longer than the observed mean duration of mating flights (Drescher, 1969). These facts reflect the drones' absence from the foraging process, and suggest that even their limited crop capacity is sufficient to provide energy for mating flights. But the relatively low crop contents together with the small glycogen reserves also means that drones are at high risk to starve by completely depleting their energy reserves on homing flights.

While we have information about the transport of liquid and solid food in the workers' alimentary canal (Schreiner, 1952; Lorenz and Crailsheim, 1994), little is known about this process in drones. Gmeinbauer and Crailsheim (1993) found that drones which were subjected to exhaustive flights in a roundabout were emptying their crop more quickly than worker bees of foraging age subjected to the same procedure. This finding possibly reflects the function of the worker's crop as storage organ of carbohydrate food, most of which is transferred to other members of the colony or deposited as honey in the cells. In contrast, food ingested by a drone is used only by the drone itself and not passed on to others (reviewed by Crailsheim, 1998).

The hypopharyngeal glands, present only in workers, are voluminous in young adults but decrease in size under normal conditions in old, forager-age, individuals (Maurizio, 1954; Hrassnigg and Crailsheim, 1998b; also reviewed by Crailsheim, 1990). Furthermore, they change their function from the synthesis of jelly proteins in young workers to the production, in old workers, of various carbohydrate-processing enzymes, like $\alpha$-glucosidases (= saccharase 
or invertase, and maltase) (Maurizio, 1962; Simpson et al., 1968; Delage-Darchen et al., 1982; Kubo et al., 1996), $\beta$-glucosidase (Pontoh and Low, 2002), glucose oxidase and amylase (Takenaka et al., 1990; Ohashi et al., 1999), and several other enzymes (Arnold and DelageDarchen, 1978). The role of $\alpha$-glucosidase and glucose oxidase is more clearly understood than the function of amylase, which is considered to be involved in the digestion of pollen. In drones these enzymes are certainly not produced by hypopharyngeal glands, as drones lack these glands (Snodgrass, 1956), so that we may ask whether other glands or the midgut cells compensate.

In workers, midgut cells produce various enzymes. In the posterior midgut regulated enzyme secretion was described for acid phosphatase, nonspecific esterase activity, and alkaline phosphatase activity (Jimenez and Gilliam, 1990). Several other enzymes have also been detected, such as esterases, lipases, aminopeptidases, proteases, and glucosidases (Maurizio, 1962; Delage-Darchen et al., 1982). The proteases have been investigated in the most detail (Pavlovsky and Zarin, 1922; Giebel et al., 1971; Dahlman et al., 1978; Grogan and Hunt, 1980; 1984; Moritz and Crailsheim, 1987; Crailsheim and Stolberg, 1989; Del Lama et al., 2001).

In drones, the location where digestive enzymes are produced and the amounts produced have not been investigated as well. Pavlovsky and Zarin (1922) found qualitatively no differences in the midgut enzymes between workers and drones (carbohydrases, proteases, lipase and others). But Giebel et al. (1971) described clear qualitative differences within the class of proteases. In drones, as in workers, the level of proteolytic activity in the midgut corresponds to the amount of pollen present there (Szolderits and Crailsheim, 1993). But in drones the level of this activity was found to be lower than in workers. The reason for the lower proteolytic activity is probably related to the low pollen consumption rate and the fact that drones, especially young ones, are intensely fed by the workers (Free, 1957), who provide them not only carbohydrates but also proteinaceous secretions (Mindt, 1962; Crailsheim, 1991, 1992).

About the activity of carbohydrases in the drones' gastrointestine we have almost no infor- mation. However, we recently demonstrated that the amylase activity in the drone midgut is not sufficient to degrade starch quickly after feeding and to support flight, while workers are able to utilise fed starch and to use it as fuel for flight (Hrassnigg et al., 2003b).

The information on pollen consumption, digestive enzyme activity and transfer of proteinaceous jelly in workers and drones underline the predominant function of workers in digesting food for the colony, and they show that drones rely on this pre-processed food.

\section{ENERGY METABOLISM OF WORKERS AND DRONES}

In workers and drones much of the energy ingested as carbohydrate food is used for flight muscle activity. From the measurement of the RQ of resting and flying bees, which was always found to be close to unity, it can be deduced that honeybees utilise only carbohydrates as fuel for energy metabolism (Jongbloed and Wiersma, 1935; Rothe and Nachtigall, 1989). Workers are able to actively heat with their flight muscles by vibrating their thoracic muscles without moving the wings (Esch et al., 1991; Heinrich and Esch, 1994). The ability to actively generate heat is a prerequisite for launching into flight at low ambient temperatures (Harrison and Fewell, 2002), and this ability is used to warm the brood nest area of a honeybee colony to about $34-36{ }^{\circ} \mathrm{C}$ (Heinrich, 1993; Bujok et al., 2002; Kleinhenz et al., 2003). Adult workers of different ages, except very young ones, actively participate in this thermoregulation of the brood nest (Stabentheiner and Kovac, 2002). In active worker bees, oxygen consumption rates decrease with increasing temperatures (Cahill and Lustick, 1976; Stabentheiner et al., 2003); the higher oxygen consumption at lower temperatures is caused by increased thoracic heating (Stabentheiner and Crailsheim, 1999; Crailsheim et al., 1999). Drones older than 2 days also contribute to active heat production, mainly at low ambient temperatures (Harrison, 1987; Kovac and Stabentheiner, 2002), but temperature-related energy metabolism in drones has not been investigated as well as in workers. Groups of caged drones kept at different ambient temperatures exhibited very different behaviours than workers. At temperatures from 5 to $20^{\circ} \mathrm{C}$ 
drones were ectothermic (= body temperature oscillating with ambient temperature), while workers were endothermic (Cahill and Lustick, 1976). But at temperatures between 25 and $35^{\circ} \mathrm{C}$, both drones and workers were endothermic. Chill coma temperature - i.e. the temperature at which the animal becomes motionless - was found to be higher in drones $\left(\sim 14^{\circ} \mathrm{C}\right)$ than in workers $\left(\sim 11^{\circ} \mathrm{C}\right)$ (Free and SpencerBooth, 1960), and was found to be even more elevated in inbred drones (Moritz, 1982). Similarly, the extinction temperature of flight muscles, which is the temperature at which no muscle potential amplitudes are generated any more and flight muscles cannot be activated, was $1-2{ }^{\circ} \mathrm{C}$ higher in drones $\left(13.3{ }^{\circ} \mathrm{C} \pm 1.2\right)$ than in workers $\left(11.2^{\circ} \mathrm{C} \pm 0.7\right.$ ) (Goller and Esch, 1990a, b). The heating capacity of flight muscles declines with decreasing thoracic temperatures. Low temperatures $\left(<20^{\circ} \mathrm{C}\right)$ affect heat production in drones more than in workers (Goller and Esch, 1991), so that drones usually leave the colony only at higher ambient temperatures $\left(>20^{\circ} \mathrm{C}\right.$ ) for longer flights (Drescher, 1969). But workers and drones not only have to increase temperature to a specific level, they also have to keep thermal stability during flight by cooling or adapting their metabolic rate (Coelho, 1991a, b; Roberts and Harrison, 1999; Moffatt, 2001; Harrison and Fewell, 2002).

The worker's flight capacity increases towards foraging age (Harrison, 1986). The body mass decreases by $\sim 40 \%$, with the most pronounced decline in the weight of midgut and rectum (Harrison, 1986; Hrassnigg and Crailsheim, 1998a), and also a significant decline in head weight (Hrassnigg and Crailsheim, 1998b). For drones no such pronounced decrease in weight has been observed. In workers and drones the flight muscles are not fully developed at emergence. Wing muscle mitochondria increase in volume 12-fold in workers from emergence to 20 days of age (Herold, 1965), and also the concentrations of respiratory enzymes, the cytochromes $\mathrm{a}+\mathrm{a} 3, \mathrm{~b}+\mathrm{c} 1$, and $\mathrm{c}$, increase in parallel (Herold and Borei, 1963). So, in foraging-age workers a high content of respiratory enzymes per unit muscle mass is found, and these enzymes are accommodated by abundant mitochondria and high cristae surface densities (Suarez et al., 1999, 2000). Also citric cycle enzyme activity increases in ageing bees. Moritz (1988) found malate dehydrogenase activity to reach its maximum activity in drones earlier than in workers (at 4 days of age in drones and 9-10 days of age in workers). For pyruvate kinase and citrate synthetase, Harrison (1986) found maximum activity in 4d-old workers, but he gives no data about drones.

Coelho (1991a) found in tethered flying honeybees the maximal force production of drones to be more than twice that of workers $(3.95 \pm 0.23 \mathrm{mN}$ and $1.73 \pm 0.13 \mathrm{mN})$. But calculated on a total body-weight basis the relative force produced was statistically not different for drones and for workers: $19.4 \pm 1.0 \mathrm{~N} / \mathrm{kg}$ in drones vs. $21.0 \pm 1.6 \mathrm{~N} / \mathrm{kg}$ in workers. It is interesting to note that maximal force production was attained in drones at higher thorax temperatures than in workers. The results of Coelho (1991a, b) also suggest that drones have to reach a higher thorax temperature at preflight warm-up to achieve lift-off. This is supported by the fact that the mean thorax temperatures of drones flying from the hive and returning to it were found to be higher than those of workers (Coelho, 1991a; Kovac and Stabentheiner, 2004). Some measurements of flight velocity in freely flying bees found drones to be slower than workers, 5.28 \pm $0.10 \mathrm{~m} / \mathrm{s}$ vs. $5.85 \pm 0.08 \mathrm{~m} / \mathrm{s}$ (Coelho, 1991b). Another report states that drones were able to follow a tethered queen at $5 \mathrm{~m} / \mathrm{s}$ (Koeniger, 1988). But even if drones do not fly faster than workers, their larger body mass increases their kinetic energy, and might have advantages in the course of aggressive encounters between males (Coelho, 1996).

\section{CONCLUSIONS}

The superorganism honeybee colony passes its genes to the next generation either by producing queens which establish new colonies, or by producing competitive drones which mate with queens from other colonies. Multiple mating of queens evolved as a successful strategy in A. mellifera (Page, 1986; Moritz and Fuchs, 1998). The sperm limitation hypotheses and the genetic variance hypotheses try to explain the causes for these multiple matings (Fuchs and Moritz, 1998; Tarpy and Page 2002; Kraus et al., 2004). Within a group of sister colonies the male mating success was, for unknown reasons, much higher in some colonies than the success of drones from other colonies in the 
group (Kraus et al., 2003). Individual drones from the more successful colonies had a higher siring success, which was represented in a higher proportion of offspring. Therefore Kraus et al. (2003) conclude that the male reproductive success is a "major driver of natural selection in honeybees" and "selection through the male side appears to be an extremely important factor for colony fitness". These aspects might have supported the evolution of big males which, probably for physiological reasons, produce more sperm than small males and which develop a higher kinetic energy at flight which could be advantageous to outcompete other drones. Males of A. mellifera gain their high final body weight after a prolonged developmental period, during which spermatogenesis and organ formation occurs. Adult drones are characterised by a lower direct pollen consumption and lower digestive enzyme levels in the gastrointestine than found in workers, although their need for nutrients is quite high. The workers provide them with pre-digested food, via proteinaceous glandular secretions and honey. This enhances the workers' control over drones and facilitates additional support under flourishing colony conditions as well as rejection during dearth periods. Similar to queens, drones exhibit higher levels of free amino acids in the hemolymph. Their higher chill coma temperature might explain why they usually leave the hive at rather warm temperatures only. Drones and workers have similar high amounts of carbohydrate and lipid reserves as larvae, and smaller reserves as adults. The yolk protein vitellogenin has been found in the hemolymph of adult workers and drones, as has juvenile hormone, which stimulates flight behaviour in both workers and drones. Workers and drones seem to have a similar sugar spectrum in the hemolymph, too.

A colony invests a lot of resources into the rearing and maintenance of a certain number of drones during the reproduction period (Seeley, 2002). The drones are constructed for the single purpose of finding and mating with a queen. Their physiology reflects the intensive care they receive from workers, characterised by a reduction in such functions as the ability to collect and digest nectar and pollen, and by a reduction of the glands that produce jelly, enzymes and wax. Their body composition is specialised for containing and transferring large amounts of sperm and mucus, the latter having important functions in the mating process, one of which is to support the connection of drone and queen, and probably in the stimulation of oogenesis and oviposition. Their flight strategy is more risky than that of workers, as they carry only relatively small amounts of sugar solutions on their mating flights as well as small glycogen reserves, and as they are not providing themselves with nectar in the field like workers do.

\section{ACKNOWLEDGEMENTS}

We are grateful to Richard Nowogrodzki for his comments and linguistic corrections and to two anonymous reviewers for improving the manuscript.

Résumé - Différences physiologiques entre les mâles et les ouvrières de l'Abeille domestique (Apis mellifera). L'investissement pour élever une larve de mâle est double de celui d'une larve d'ouvrière. Cela se reflète dans le poids élevé des mâles adultes qui sont plus de deux fois plus lourds (Tab. I). On peut déduire des mesures directes et des quotients respirométriques que les larves d'ouvrières et de mâles synthétisent de grandes quantités de glycogène et de lipides comme substances de réserve. Ces substances de réserve représentent environ la moitié de la substance sèche des larves des deux types. La quantité de glycogène et de lipides diminue au cours de la métamorphose et, à l'émergence des adultes, la teneur en ces substances est très basse, chez les ouvrières comme chez les mâles (Tab. II). C'est pourquoi les insectes adultes ne peuvent survivre longtemps sans se nourrir. Diverses recherches ont montré qu'après l'émergence la teneur en protéines corporelles augmente considérablement chez les ouvrières et les mâles (Fig. 1, Tab. III). Mais, tandis que les ouvrières ingèrent du pollen en masse, les mâles ne consomment que de petites quantités et présentent une activité protéolytique réduite dans l'intestin moyen. C'est pourquoi le nourrissement des mâles par les ouvrières, qui leur donnent de la gelée royale riche en protéines, est important pour la maturation finale du corps. Les glandes hypopharyngiennes, qui secrètent principalement des enzymes glycolytiques chez les ouvrières âgées, fournissent la plus grosse partie de ces protéines. Chez les mâles les glandes hypopharyngiennes sont absentes, en conséquence ils ne peuvent pas synthétiser des enzymes, comme l'amylase. La capacité à produire ces enzymes place les ouvrières, mais non les mâles, dans la position de dégrader rapidement des amidons solubles et de les convertir peu après leur ingestion pour le métabolisme de vol. Nous déduisons de cela et de mesures 
directes d'enzymes protéolytiques que les mâles possèdent une quantité réduite d'enzymes de digestion. Cela souligne l'importance du «service de digestion » des ouvrières. Le quotient respiratoire chez les ouvrières adultes qui volent est proche de un. Il est donc très vraisemblable qu'aucune autre substance que les glucides n'est utilisée pour obtenir l'énergie nécessaire au vol. Chez les mâles la concentration de l'hémolymphe en acides aminés libres est significativement supérieure à celle des ouvrières. La proline en constitue la plus grosse partie, atteignant $80 \%$ chez les ouvrières et $50 \%$ chez les mâles ; elle joue peut-être un rôle plus important dans le métabolisme énergétique qu'il n'a été admis jusqu'à présent. La force qui produit la musculature de vol des mâles est le double de celle des ouvrières, qui par ailleurs est aussi grande si on la rapporte à l'unité de poids. Avant le vol les mâles élèvent la température des muscles du thorax à un niveau supérieur à celui des ouvrières, vraisemblablement afin d'obtenir une force suffisante pour l'envol. Ils sont plus sensibles aux basses températures que les ouvrières, car ils sont plus vite engourdis par le froid. Dans la colonie d'abeilles les mâles ne participent pas à la maintenance du nid et ne sont pas non plus impliqués dans la division du travail. Malgré cela les ouvrières investissent d'importantes ressources dans les mâles en raison de leur fonction de reproduction. Par un poids corporel plus élevé, des glandes réduites et une capacité de digestion plus faible, les mâles ont une physiologie adaptée à cette fonction, si bien qu'ils dépendent d'une nourriture concentrée de haute qualité, à savoir le miel et la gelée royale produite par les ouvrières.

nutrition / digestion / enzyme / métabolisme énergétique / substance de réserve

Zusammenfassung - Physiologische Unterschiede zwischen Drohnen und Arbeiterinnen der Honigbiene (Apis mellifera). Das Investment um eine Drohnenlarve aufzuziehen ist etwa doppelt so groß wie jenes für eine Arbeiterinnenlarve. Dies spiegelt sich im mehr als doppelt so hohen Gewicht der adulten Drohnen (Tab. I). Von direkten Messungen und vom respiratorischen Quotienten (RQ), der in einigen Larvenstadien 1 übersteigt, kann abgeleitet werden, dass Arbeiterinnen- und Drohnenlarven große Mengen an Glykogen und Fett als Reservestoffe synthetisieren. Diese Reservestoffe machen bei beiden Larventypen ca. die Hälfte der Larventrockensubstanz aus. Während der Metamorphose sinkt die Menge an Glykogen und Fett, und in Arbeiterinnen und Drohnen ist beim Schlupf der adulten Tiere der Gehalt an beiden Substanzklassen sehr niedrig (Tab. II). Deshalb können adulte Tiere ohne Fütterung nur kurze Zeit überleben. Verschiedene Untersuchungen haben gezeigt, dass nach dem Schlüpfen der Gehalt an Körperprotein in Arbeiterinnen und Drohnen beträchtlich ansteigt (Abb. 1, Tab. III). Aber während Arbeiterinnen massiv Pol- len zu sich nehmen, verzehren Drohnen nur kleine Mengen und zeigen auch eine geringere proteolytische Aktivität im Mitteldarm. Deshalb ist die Fütterung der Drohnen mit proteinreichem Gelee royale durch die Arbeiterinnen wichtig für die finale Reifung des Körpers. Den größten Anteil an diesen Proteinen liefern die Hypopharynxdrüsen, die in älteren Arbeiterinnen hauptsächlich kohlenhydratverdauende Enzyme produzieren. In Drohnen fehlen die Hypopharynxdrüsen, deshalb können Drohnen sie auch nicht für die Synthese von Enzymen, wie Amylase, einsetzen. Die Fähigkeit diese Enzyme zu produzieren, versetzt Arbeiterinnen, jedoch nicht Drohnen, in die Lage, lösliche Stärke rasch abzubauen und diese kurz nach ihrer Verfütterung im Flugstoffwechsel zu verwerten. Daraus und aus direkten Messungen der proteolytischen Enzyme leiten wir ab, dass Drohnen eine geringere Menge an Verdauungsenzymen besitzen. Dies unterstreicht das wichtige „Verdauungsservice“ der Arbeiterinnen. Der RQ in adulten fliegenden Arbeiterinnen liegt nahe bei Eins. Dies macht es sehr wahrscheinlich, dass keine anderen Substrate als Kohlenhydrate (Zucker) für die Energiegewinnung im Flug verwendet werden. In Drohnen liegt die Konzentration an freien Aminosäuren in der Hämolymphe signifikant über jener von Arbeiterinnen, wobei Prolin den größten Anteil mit bis zu $80 \%$ in Arbeiterinnen und bis zu $52 \%$ in Drohnen ausmacht, mit einer möglicherweise wichtigeren Rolle im Energiestoffwechsel als bisher angenommen. Die Kraft, welche die Flugmuskulatur der Drohnen produziert, ist mehr als doppelt so groß als die der Arbeiterinnen, wobei allerdings die auf eine Gewichtseinheit bezogene relative Kraft ähnlich groß ist. Drohnen steigern die Temperatur der Thoraxmuskulatur vor dem Flug auf ein höheres Niveau als Arbeiterinnen, wahrscheinlich um genug Kraft für den Abflug zu erzeugen. Sie sind empfindlicher gegenüber niedrigen Temperaturen, da sie früher als Arbeiterinnen in Kältestarre fallen.

Im Honigbienenvolk arbeiten Drohnen weder für die Erhaltung des Nests noch sind sie am Arbeitsteilungssystem beteiligt. Trotzdem investieren die Arbeiterinnen beträchtliche Ressourcen, aufgrund ihrer Reproduktionsfunktion, in sie. Ihre Physiologie ist, durch ein höheres Körpergewicht, durch reduzierte Drüsen und reduzierte Verdauungskapazität, an diese Rolle angepasst. So dass sie von konzentriertem Futter mit hoher Qualität, nämlich dem Honig und dem von Arbeiterinnen produzierten Gelee royale, abhängig sind.

Ernährung / Verdauung / Enzyme / Energiestoffwechsel / Reservestoffe

\section{REFERENCES}

Abou-Seif M.A.M., Maier V., Fuchs J., Mezger M., Pfeiffer E.F., Bounias M. (1993) Fluctuations of 
carbohydrates in haemolymph of honeybee (Apis mellifica) after fasting, feeding and stress, Horm. Metab. Res. 25, 4-8.

Adam G.V., Norberg K., Hagen A., Omholt S.W. (2003) Social exploitation of vitellogenin, Proc. Natl. Acad. Sci. (USA) 100, 1799-1802.

Albrecht G. (1961) Untersuchungen über die chemische Zusammensetzung einiger Insektenfette, Z. Vgl. Physiol. 44, 487-508.

Allen M.D. (1958) Drone brood in honey bee colonies, Z. Bienenforsch. 51, 46-48.

Allen M.D. (1959) Respiration rates of larvae of drone and worker honey bees, Apis mellifera L., J. Econ. Entomol. 52, 399-402.

Alumot E., Lensky Y., Holstein P. (1969) Sugars and trehalase in the reproductive organs and hemol$\mathrm{ymph}$ of the queen and drone honey bees (Apis mellifica L. var. ligustica Spin.), Comp. Biochem. Physiol. 28, 1419-1425.

Arnold G., Delage-Darchen B. (1978) Nouvelles données sur l'équipement enzymatique des glandes salivaires de l'ouvrière d'Apis mellifica (Hymenoptere Apide), Ann. Sci. Nat. Zool. 20, 401-422.

Arslan A., Standifer L.N., Don H. (1986) Carbohydrate in honey bee hemolymph, Comp. Biochem. Physiol. 84B, 363-367.

Babendreier D. Kalberer N., Romeis J., Fluri P. Bigler F. (2004) Pollen consumption in honey bee larvae: a step forward in the risk assessment of transgenic plants, Apidologie 35, 293-300.

Barker R.J., Lehner Y. (1972) Free amino acids in thoraces of flown honey bees, Apis mellifera L. (Hymenoptera: Apidae), Comp. Biochem. Physiol. 43B, 163-169.

Beenakkers A.M.T. (1969) Carbohydrate and fat as a fuel for insect flight. A comparative study, J. Insect Physiol. 15, 353-361.

Berg S., Koeniger N., Koeniger G., Fuchs S. (1997) Body size and reproductive success of drones (Apis mellifera L.), Apidologie 28, 449-460.

Berger B., Crailsheim K., Leonhard B. (1997) Proline, leucine and phenylalanine metabolism in adult honeybee drones (Apis mellifica carnica Pollm), Insect Biochem. Mol. Biol. 27, 587-593.

Beutler R. (1937) Über den Blutzucker der Bienen, Z. Vgl. Physiol. 24, 71-115.

Bishop G.H. (1961) Growth rates of honeybee larvae, J. Exp. Zool. 146, 11-20.

Blatt J., Roces F. (2001) Haemolymph sugar levels in foraging honeybees (Apis mellifera carnica): dependence on metabolic rate and in vivo measurement of maximal rates of trehalose synthesis, J. Exp. Biol. 204, 2709-2716.

Blatt J., Roces F. (2002) The control of the proventriculus in the honeybee (Apis mellifera carnica L.). I. A dynamic process influenced by food quality and quantity? J. Insect Physiol. 48, 643-654.
Bounias M. (1981) A comparison of haemolymph levels and inter-relations of trehalose, glucose and fructose in workerbees from different races and hybrids, Comp. Biochem. Physiol. 69B, 471-477.

Bounias M., Debevec M., Popeskovic D. (1985) A comparison of haemolymph lipid classes at different stages of honeybee development, Acta Vet. (Beograd) 35, 273-282.

Bowen-Walker P.L., Gunn A. (2001) The effect of the ectoparasitic mite, Varroa destructor on adult worker honeybee (Apis mellifera) emergence weights, water, protein, carbohydrate, and lipid levels, Entomol. Exp. Appl. 101, 207-217.

Bozic J., Woodring J. (1997) Effect of activity on the haemolymph sugar titres in honey bees, J. Apic. Res. 36, 33-39.

Brouwers E.V.M. (1982) Measurement of hypopharyngeal gland activity in the honeybee, J. Apic. Res. 21, 193-198.

Brouwers E.V.M. (1984) Glucose/fructose ratio in the food of honeybee larvae during caste differentiation, J. Apic. Res. 23, 94-101.

Brouwers E.V.M., Ebert R., Beetsma J. (1987) Behavioural and physiological aspects of nurse bees in relation to the composition of larval food during caste differentiation in the honeybee, J. Apic. Res. $26,11-23$.

Bujok B., Kleinhenz M., Fuchs S., Tautz J. (2002) Hot spots in the bee hive, Naturwissenchaften 89, 299301.

Burgett D. M. (1973) Drone engorgement in honey bee swarms, Ann. Entomol. Soc. Am. 66, 1005-1006.

Cahill K., Lustick S. (1976) Oxygen consumption and thermoregulation in Apis mellifera workers and drones, Comp. Biochem. Physiol. 55A, 355-357.

Calderone N.W. (1998) Proximate mechanisms of age polyethism in the honey bee, Apis mellifera L., Apidologie 29, 127-158.

Calderone N.W., Kuenen L.P.S. (2003) Differential tending of worker and drone larvae of the honey bee, Apis mellifera, during the 60 hours prior to cell capping, Apidologie 34, 543-552.

Cantrill R.C., Hepburn H.R., Warner S.J. (1981) Changes in lipid composition during sealed brood development of African worker honeybees, Comp. Biochem. Physiol. 68B, 351-353.

Coelho J.R. (1991a) The effect of thorax temperature on force production during tethered flight in honeybee (Apis mellifera) drones, workers, and queens, Physiol. Zool. 64, 823-835.

Coelho J.R. (1991b) Heat transfer and body temperature in honey bee (Hymenoptera: Apidae) drones and workers, Environ. Entomol. 20, 1627-1635.

Coelho J.R. (1996) The flight characteristics of drones in relation to mating, Bee Sci. 4, 21-25.

Colonello N.A., Hartfelder K. (2003) Protein content and pattern during mucus gland maturation and its ecdysteroid control in honey bee drones, Apidologie 34, 257-267. 
Colonello N.A., Hartfelder K. (2005) She's my girl male accessory gland products and their function in the reproductive biology of social bees, Apidologie 36, 231-244.

Crailsheim K. (1990) The protein balance of the honey bee worker, Apidologie 21, 417-429.

Crailsheim K. (1991) Interadult feeding of jelly in honeybee (Apis mellifera L.) colonies, J. Comp. Physiol. 161B, 55-60.

Crailsheim K. (1992) The flow of jelly within a honeybee colony, J. Comp. Physiol. 162B, 681-689.

Crailsheim K. (1998) Trophallactic interactions in the adult honeybee (Apis mellifera L.), Apidologie 29, 97-112.

Crailsheim K., Stolberg E. (1989) Influence of diet, age and colony condition upon intestinal proteolytic activity and size of the hypopharyngeal glands in the honeybee (Apis mellifera L.), J. Insect Physiol. 35, 595-602.

Crailsheim K., Leonhard B. (1997) Amino acids in honeybee worker haemolymph, Amino Acids 13, 141-153.

Crailsheim K., Schneider L.H.W., Hrassnigg N., Bühlmann G., Brosch U., Gmeinbauer R. Schöffmann B. (1992) Pollen consumption and utilization in worker honeybees (Apis mellifera carnica): Dependence on individual age and function, J. Insect Physiol. 38, 409-419.

Crailsheim K., Jin P., Pfeiffer K.J., Pabst M.A. (1997) Der Proteingehalt junger Drohnen der Honigbiene (Apis mellifera L.), Mitt. Dtsch. Ges. Allg. Angew. Entomol. 11, 167-168.

Crailsheim K., Stabentheiner A., Hrassnigg N., Leonhard B. (1999) Oxygen consumption at different activity levels and ambient temperatures in isolated honeybees (Hymenoptera: Apidae), Entomol. Gen. 24, 1-12.

Cremonez T.M., De Jong D., Bitondi M.M.G. (1998) Quantification of hemolymph proteins as a fast method for testing protein diets for honey bees (Hymenoptera: Apidae), J. Econ. Entomol. 91, 1284-1289.

Czoppelt Ch., Rembold H. (1970) Vergleichende Analyse des Kohlenhydratstoffwechsels bei den Kasten der Honigbiene, Apis mellifera, J. Insect Physiol. 16, 1249-1264.

Dahlmann B., Jany K.-D., Pfleiderer G. (1978) The midgut endopeptidases of the honey bee (Apis mellifica): Comparison of the enzymes in different ontogenetic stages, Insect Biochem. 8, 203-211.

Del Lama M.A., Bezerra R.M., Egea Soares A.E., Ruvolo-Takasusuki M.C. (2001) Genetic, ontogenetic, and tissue-specific variation of aminopeptidases of Apis mellifera, Apidologie 32, 25-35.

De Groot A.P. (1950) The influence of temperature and kind of food on the increase in the nitrogen content of the young worker honeybee (Apis mellifica L.), Proc. K. Ned. Akad. Wet. Ser. C 53, Zoology, 560-566.
De Groot A.P. (1953) Protein and amino acid requirements of the honeybee (Apis mellifica L.), Physiol. Comp. Oecol. 3, 197-285.

Delage-Darchen B., de Conconi J.R., Aguilar I.C. (1982) The enzymatic equipments of the various salivary and midgut glands of Apis mellifica workers and some african and american worker stingless bees, Apidologie 13, 265-273.

Drescher W. (1969) Die Flugaktivität der Drohnen der Rasse Apis mellifica carnica L. und A. mell. ligustica L. in Abhängigkeit von Lebensalter und Witterung, Z. Bienenforsch. 9, 390-409.

Duay P., DeJong D., Engels W. (2003) Weight loss in drone pupae (Apis mellifera) multiply infested by Varroa destructor mites, Apidologie 34, 61-65.

Elekonich M.M., Schulz D.J., Bloch G., Robinson G.E. (2001) Juvenile hormone levels in honey bee (Apis mellifera L.) foragers: foraging experience and diurnal variation, J. Insect Physiol. 47, 11191125.

Engels W. (1974) Occurrence and significance of vitellogenin in female castes of social Hymenoptera, Am. Zool. 14, 1229-1237.

Engels W., Fahrenhorst H. (1974) Alters- und kastenspezifische Veränderungen der Haemolymph-Protein-Spektren bei Apis mellifica, W. Roux' Arch. 174, 285-296.

Engels W., Kaatz H., Zillikens A., Simoes Z.L.P., Trube A., Braun R., Dittrich F. (1990) Honey bee reproduction: Vitellogenin and caste-specific regulation of fertility, Adv. Invertebr. Reprod. 5, 495502.

Esch H., Goller F., Heinrich B. (1991) How do bees shiver? Naturwissenschaften 78, 325-328.

Fahrbach S.E. (1997) Regulation of age polyethism in bees and wasps by juvenile hormone, Adv. Study Behav. 26, 285-316.

Fluri P., Bodganov S. (1982) Age dependence of fat body protein in summer and winter bees (Apis mellifera), in: Eder J., Rembold N. (Eds.), Chemistry and biology of social insects, Verlag J. Peperny, München, pp. 170-171.

Free J.B. (1957) The food of adult drone honeybees (Apis mellifera), Br. J. Anim. Behav. 5, 7-11.

Free J.B., Spencer-Booth Y. (1960) Chill-coma and cold death temperatures of Apis mellifera, Entomol. Exp. Appl. 3, 222-230.

Free J.B., Williams I. H. (1975) Factors determining the rearing and rejection of drones by the honeybee colony, Anim. Behav. 23, 650-675.

Fuchs S., Moritz R.F.A. (1998) Evolution of extreme polyandry in the honeybee Apis mellifera L., Behav. Ecol. Sociobiol. 45, 269-275.

Fukuda H., Ohtani T. (1977) Survival and life span of drone honeybees, Res. Popul. Ecol. 19, 51-68.

Fyg W. (1965) Über die Lokalisation des Glycogens in den larvalen und pupalen Fettkörperzellen der Honigbiene, Z. Bienenforsch. 8, 55-70. 
Gary N.E. (1963) Observations of mating behaviour in the honeybee, J. Apic. Res. 2, 3-13.

Giebel W., Zwilling R., Pfleiderer G. (1971) The evolution of endopeptidases - XII. The proteolytic enzymes of the honeybee (Apis mellifica L.), Comp. Biochem. Physiol. 38B, 197-210.

Giray T., Robinson G.E. (1996) Common endocrine and genetic mechanisms of behavioral development in male and worker honey bees and the evolution of division of labor, Proc. Natl. Acad. Sci. (USA) 93, 11718-11722.

Glinski Z., Jarosz J. (1984) Alterations in haemolymph proteins of drone honey bee larvae parasitized by Varroa jacobsoni, Apidologie 15, 329-338.

Gmeinbauer R., Crailsheim K. (1993) Glucose utilization during flight of honeybee (Apis mellifera) workers, drones and queens, J. Insect Physiol. 39, 959-967.

Goller F., Esch H.E. (1990a) Muscle potentials and temperature acclimation and acclimatization in flight muscles of workers and drones of Apis mellifera, J. Therm. Biol. 15, 307-312.

Goller F., Esch H.E. (1990b) Comparative study of chill-coma temperatures and muscle potentials in insect flight muscles, J. Exp. Biol. 150, 221-231.

Goller F., Esch H.E. (1991) Oxygen consumption and flight muscle activity during heating in workers and drones of Apis mellifera, J. Comp. Physiol. 161B, 61-67.

Gontarski H. (1953) Zur Brutbiologie der Honigbiene, Z. Bienenforsch. 2, 7-10.

Grogan D.E., Hunt J.H. (1980) Age correlated changes in midgut protease activity of the honeybee, Apis mellifera (Hymenoptera: Apidae), Experientia 36, $1347-1348$

Grogan D.E., Hunt J.H. (1984) Chymotrypsin-like activity in the honeybee midgut: patterns in a three-year study, J. Apic. Res. 23, 61-63.

Harbo J.R., Bolten A.B. (1981) Development times of male and female eggs of the honey bee, Ann. Entomol. Soc. Am. 74, 504-506.

Harrison J.M. (1986) Caste-specific changes in honeybee flight capacity, Physiol. Zool. 59, 175-186.

Harrison J.M. (1987) Roles of individual honeybee workers and drones in colonial thermogenesis, J. Exp. Biol. 129, 53-61.

Harrison J.F., Fewell J.H. (2002) Environmental and genetic influences on flight metabolic rate in the honey bee, Apis mellifera, Comp. Biochem. Physiol. 133A, 323-333.

Harrison J.F., Suarez P.K. (2004) Insect flight takes off, J. Exp. Biol. 207, 3251-3252.

Hartfelder K. (1990) Regulatory steps in cast development of eusocial bees, in: Engels W. (Ed.), Social Insects - An evolutionary approach to castes and reproduction, Springer Verlag, Berlin, Heidelberg, New York, pp. 245-264.

Hartfelder K., de Oliveira Tozetto S., Rachinsky A. (1993) Sex specific developmental profiles of juvenile hormone synthesis in honey bee larvae, Roux's Arch. Dev. Biol. 202, 176-180.

Haydak M.H. (1934) Changes in total nitrogen content during the life of the imago of the worker honeybee, J. Agric. Res. 49, 21-28.

Haydak M.H. (1937a) Changes in weight and nitrogen content of adult worker bees on a protein-free diet, J. Agric. Res. 54, 791-796.

Haydak M.H. (1937b) The influence of a pure carbohydrate diet on newly emerged honeybees, Ann. Entomol. Soc. Am. 30, 258-262.

Haydak M.H. (1957a) The food of the drone larvae, Ann. Entomol. Soc. Am. 50, 73-75.

Haydak M.H. (1957b) Changes with age in the appearance of some internal organs of the honeybee, Bee World 38, 197-207.

Haydak M.H. (1959) Changes with age in weight and nitrogen content of honeybees, Bee World 40, 225-229.

Haydak M.H. (1970) Honey bee nutrition, Annu. Rev. Entomol. 15, 143-156.

Heinrich B. (1993) The Hot-blooded Insects, Springer Verlag, Berlin, Heidelberg, p. 601.

Heinrich B., Esch H. (1994) Thermoregulation in bees, Am. Sci. 82, 164-170.

Henderson C.E. (1991) Variability in the size of emerging drones and of drone and worker eggs in honey bee (Apis mellifera L.) colonies, J. Apic. Res. 31, 114-118.

Hepburn H.R., Cantrill R.C., Thompson P.R., Kennedi E. (1979) Metabolism of carbohydrate, lipid and protein during development of sealed worker brood of the African honeybee, J. Apic. Res. 18, 30-35.

Herold R.C. (1965) Development and ultrastructural changes of sarcosomes during honey bee flight muscle development, Dev. Biol. 12, 269-286.

Herold R.C., Borei H. (1963) Cytochrome changes during honey bee flight muscle development, Dev. Biol. 8, 67-79.

Hoffmann I. (1966) Gibt es bei Drohnen von Apis mellifica L. ein echtes Füttern oder nur eine Futterabgabe? Z. Bienenforsch. 8, 249-255.

Hrassnigg N., Crailsheim K. (1998a) The influence of brood on the pollen consumption of worker bees (Apis mellifera L.), J. Insect Physiol. 44, 393-404.

Hrassnigg N., Crailsheim K. (1998b) Adaptation of hypopharyngeal gland development to the brood status of honeybee (Apis mellifera L.), J. Insect Physiol. 44, 929-939.

Hrassnigg N., Leonhard B., Crailsheim K. (2003a) Free amino acids in the haemolym of honey bee queens (Apis mellifera L.), Amino Acids 24, $205-$ 212.

Hrassnigg N., Brodschneider R., Fleischmann P., Crailsheim K. (2003b) Worker bees (Apis mellifera L.) are able to utilize starch as fuel for flight while drones are not, 38th Apimondia Int. Apic. 
Congr., 24-29 August 2003, in Ljubljana, Slovenia.

Huang Z.Y., Robinson G.E., Tobe S.S., Yagi K.J., Strambi C., Strambi A., Stay B. (1991) Hormonal regulation of behavioural development in the honey bee is based on changes in the rate of juvenile hormone biosynthesis, J. Insect Physiol. 37, 733-741.

Imdorf A., Rickli M., Kilchenmann V., Bogdanov S., Wille H. (1998) Nitrogen and mineral constituents of honey bee worker brood during pollen shortage, Apidologie 29, 315-325.

Jassim O., Huang Z.Y., Robinson G.E. (2000) Juvenile hormone profiles of worker honey bees, Apis mellifera, during normal and accelerated behavioural development, J. Insect Physiol. 46, 243-249.

Jay S.C. (1963) The development of honeybees in their cells, J. Apic. Res. 2, 117-134.

Jaycox E.R. (1961) The effects of various foods and temperatures on sexual maturity of the drone honey bee (Apis mellifera), Ann. Entomol. Soc. Am. 54, 519-523.

Jimenez D.R., Gilliam M. (1990) Ultrastructure of the ventriculus of the honey bee, Apis mellifera (L.): cytochemical localization of acid phosphatase, alkaline phosphatase, and nonspecific esterase, Cell Tissue Res. 261, 431-443.

Jongbloed J., Wiersma C.A.G. (1935) Der Stoffwechsel der Honigbiene während des Fliegens, Z. Vgl. Physiol. 21, 519-533.

Kleinhenz M., Bujok B., Fuchs S., Tautz J. (2003) Hot bees in empty broodnest cells: heating from within, J. Exp. Biol. 206, 4217-4231.

Klenk M., Koeniger G., Koeniger N., Fasold H. (2004) Proteins in spermathecal gland secretion and spermathecal fluid and the properties of a $29 \mathrm{kDa}$ protein in queens of Apis mellifera, Apidologie 35, 371-381.

Knecht D., Kaatz H.H. (1990) Patterns of larval food production by hypopharyngeal glands in adult worker honey bees, Apidologie 21, 457-468.

Koeniger G. (1976) Einfluss der Kopulation auf den Beginn der Eiablage bei der Bienenkönigin (Apis mellifica L.), Apidologie 7, 343-355.

Koeniger G. (1981) In welchem Abschnitt des Paarungsverhaltens der Bienenkönigin findet die Induktion der Eiablage statt? Apidologie 12, 329 343.

Koeniger G. (1986) Mating sign and multiple mating in the honeybee, Bee World 67, 141-150.

Koeniger G. (1988) Mating flights of honey bee drones (Apis mellifera L.). A film documentation, Biona Report 6, 29-34.

Koeniger G., Koeniger N., Mardan M., Otis G., Wongsiri S. (1991) Comparative anatomy of male genital organs in the genus Apis, Apidologie 22, 539-552.

Koeniger N., Koeniger G. (1991) An evolutionary approach to mating behaviour and drone copulatory organs in Apis, Apidologie 22, 581-590.
Koeniger N., Koeniger G. (2000) Reproductive isolation among species of the genus Apis, Apidologie 31, 313-339.

Koeniger N., Koeniger G., Wongsiri S. (1989) Mating and sperm transfer in Apis florea, Apidologie 20, 413-418.

Kovac H., Stabentheiner A. (2002) Contribution of drones of different age to heat production in a honeybee colony, Apidologie 33, 500-501.

Kovac H., Stabentheiner A. (2004) Thermographic measurement of body temperature of drones and workers (Apis mellifera carnica Pollm.) starting and landing at the hive entrance, Mitt. Dtsch. Ges. Allg. Angew. Entomol. 14, 463-466.

Krajewska K., Hryniewiecka-Szyfter Z. (1988) Histological changes in the fat body of Apis mellifera L. during larval and pupal development, Bull. Soc. Amis Sci. Lett. Poznan Ser. D, Sci. Biol. 27, 25 35 .

Kraus F.B., Neumann P., Scharpenberg H., van Praagh J., Moritz R.F.A. (2003) Male fitness of honeybee colonies (Apis mellifera L.), J. Evol. Biol. 16, 914920 .

Kraus F.B., Neumann P., van Praagh J., Moritz R.F.A (2004) Sperm limitation and the evolution of extreme polyandry in honeybees (Apis mellifera L.), Behav. Ecol. Sociobiol. 55, 494-501.

Kubo T., Sasaki M., Nakamura J., Sasagawa H. Ohashi K., Takeuchi H., Natori S. (1996) Change in the expression of hypopharyngeal-gland proteins of the worker honeybees (Apis mellifera $\mathrm{L}$.) with age and/or role, J. Biochem. 119, 291-295.

Kunert K., Crailsheim K. (1987) Sugar and protein in the food for honeybee worker larvae, in: Eder J., Rembold N. (Eds.), Chemistry and biology of social insects, Verlag J. Peperny, München, pp. 164-165.

Kunert K., Crailsheim K. (1988) Seasonal changes in carbohydrate, lipid and protein content in emerging worker honeybees and their mortality, J. Apic. Res. 27, 13-21.

Lehninger A., Nelson D., Cox M. (2001) Lehninger Biochemie, Springer Verlag, Berlin, Heidelberg, New York, p. 1342.

Lensky Y. (1971) Haemolymph proteins of the honey bee-II. Differentiation during the development of bee workers, Comp. Biochem. Physiol. 39B, 335341.

Lensky Y., Kalinsky B. (1971) Haemolymph proteins of the honey bee - III. Presence of drones' haemolymph proteins in the reproductive organs, Isr. J. Entomol. 6, 81-96.

Lensky Y., Rakover Y. (1983) Separate protein body compartments of the worker honeybee (Apis mellifera L.), Comp. Biochem. Physiol. 75B, 607615.

Lensky Y., Cassier P., Notkin M., Delorme-Joulie C., Levinsohn M. (1985) Pheromonal activity and fine structure of the mandibular glands of honeybee drones (Apis mellifera L.) (Insecta, Hymenoptera, Apidae), J. Insect Physiol. 31, 265-276. 
Leonhard B, Crailsheim K (1999) Amino acids and osmolarity in honeybee drone haemolymph, Amino Acids 17, 195-205.

Leta M.A., Gilbert C., Morse R.A. (1996) Levels of hemolymph sugars and body glycogen of honeybees (Apis mellifera L.) from colonies preparing to swarm, J. Insect Physiol. 42, 239-245.

Levin M.D., Haydak M.H. (1951) Seasonal variation in weight and ovarian development in the worker honeybee, J. Econ. Entomol. 44, 54-57.

Loidl A., Crailsheim K. (2001) Free fatty acids digested from pollen and triolein in the honeybee (Apis mellifera carnica Pollmann) midgut, J. Comp. Physiol. 171B, 313-319.

Lorenz W., Crailsheim K. (1994) Transport fester Nahrung im Darm von Honigbienen (A. mellifera L.), Mitt. Dtsch. Ges. Allg. Angew. Entomol. 9, 313-315.

Lotmar R. (1939) Der Eiweiss-Stoffwechsel im Bienenvolk (Apis mellifica) während der Überwinterung, Landw. Jahrb. Schweiz 53, 34-70.

Mackasmiel L.A.M., Fell R.D. (2000) Respiration rates in eggs of the honey bee, Apis mellifera, J. Apic. Res. 39, 125-135.

Marx R., Möbius I., Ulrich G.M., Czoppelt C., Rembold H. (1987) Changes in fat body ultrastructure during the fifth larval instar in workers, queens and drones of the honey bee, Apis mellifera L., in: Eder J., Rembold N. (Eds.), Chemistry and biology of social insects, Verlag J. Peperny, München, pp. 86-87.

Matsuka M., Watabe N., Takeuchi K. (1973) Analysis of the food of larval drone honeybees, J. Apic. Res. 12, 3-7.

Mattila H.R., Harris J.L., Otis G.W. (2001) Timing of reproduction of winter bees in honey bee (Apis mellifera) colonies, Insectes Soc. 48, 88-93.

Maurizio A. (1954) Pollenernährung und Lebensvorgänge bei der Honigbiene (Apis mellifica L.), Landw. Jahrb. Schweiz 62, 115-191.

Maurizio A. (1962) Zuckerabbau unter der Einwirkung der invertierenden Fermente in Pharynxdrüsen und Mitteldarm der Honigbiene (Apis mellifica L.), Ann. Abeille 5, 215-232.

Maurizio A. (1965) Untersuchungen über das Zuckerbild der Hämolymphe der Honigbiene (Apis mellifica L.) - I. Das Zuckerbild des Blutes erwachsener Bienen, J. Insect Physiol. 11, 745-763.

Melampy R.M., Olsan R.D. (1940) Total carbohydrate and glycogen content of the developing honeybee, Proc. Soc. Exp. Biol. Med. 45, 754-758.

Melampy R.M., Willis E.R. (1939) Respiratory metabolism during larval and pupal development of the female honeybee (Apis mellifica L.), Physiol. Zool. 12, 302-311.

Melampy R.M., Willis E.R., McGregor S.E. (1940) Biochemical aspects of the differentiation of the female honeybee (Apis mellifera L.), Physiol. Zool. 13, 283-293.

Merz R., Gerig L., Wille H., Leuthold R. (1979) Das Problem der Kurz- und Langlebigkeit bei der Ein- und Auswinterung im Bienenvolk (Apis mellifica L.): Eine Verhaltensstudie, Rev. Suisse Zool. 86, 663-671.

Micheu S., Crailsheim K., Leonhard B. (2000) Importance of proline and other amino acids during honeybee flight, Amino Acids 18, 157-175.

Mindt B. (1962) Untersuchungen über das Leben der Drohnen, insbesondere Ernährung und Geschlechtsreife, Z. Bienenforsch. 6, 9-33.

Moffatt L. (2001) Metabolic rate and thermal stability during honeybee foraging at different reward rates, J. Exp. Biol. 204, 759-766.

Moritz B., Crailsheim K. (1987) Physiology of protein digestion in the midgut of the honeybee (Apis mellifera L.), J. Insect Physiol. 33, 923-931.

Moritz R.F.A. (1982) Inzuchteffekte auf den Stoffwechsel von Drohnen (Apis mellifera carnica), Z. Tierzücht. Züchtungsbiol. 99, 69-80.

Moritz R.F.A. (1988) Biochemical changes during honey bee flight muscle development, Biona Report 6, 51-64.

Moritz R.F.A., Fuchs S. (1998) Organization of honeybee colonies: characteristics and consequences of a superorganism concept, Apidologie 29, 7-21.

Moritz R.F.A., Neumann P. (2004) Differences in nestmate recognition for drones and workers in the honeybee, Apis mellifera (L.), Anim. Behav. 67, 681-688.

Morse R.A., Strang G.E., Nowakowski J. (1967) Fall death rates of drone honey bees, J. Econ. Entomol. 60, 1198-1202.

Morton K. (1951) The food of worker bees of different ages, Bee World 32, 78-79.

Naiem E.-S., Hrassnigg N., Crailsheim K. (1999) Nurse bees support the physiological development of young bees (Apis mellifera L.), J. Comp. Physiol. 169B, 271-279.

Nelson J.A., Sturtevant A.P., Lineburg B. (1924) Growth and feeding of honeybee larvae, U.S. Dept. Agric. Bull. No. 1222, 1-38.

Neukirch A. (1982) Dependence of the life span of the honeybee (Apis mellifica) upon flight performance and energy consumption, J. Comp. Physiol. 146, 35-40.

Ohashi K., Natori S., Kubo T. (1999) Expression of amylase and glucose oxidase in the hypopharyngeal gland with an age-dependent role change of the worker honeybee (Apis mellifera L.), Eur. J. Biochem. 265, 127-133.

Pabst M.A., Crailsheim K. (1990) The proventriculus of worker honeybee pupae, adult workers, drones and queens (Apis mellifera L.), Zool. Jahrb. Physiol. 94, 271-289.

Page R.E. Jr. (1986) Sperm utilization in social insects, Annu. Rev. Entomol. 31, 297-320.

Panzenböck U., Crailsheim K. (1997) Glycogen in honeybee queens, workers and drones (Apis mellifera carnica Pollm.), J. Insect Physiol. 43, 155165. 
Pavlovsky E.N., Zarin E.J. (1922) On the structure of the alimentary canal and its ferments in the bee (Apis mellifera L.), Q. J. Microsc. Sci. 56, 509556.

Petz M., Stabentheiner A., Crailsheim K. (2004) Respiration of individual honeybee larvae in relation to age and ambient temperature, J. Comp. Physiol. 174B, 511-518.

Phiancharoen M., Wongsiri S., Koeniger N., Koeniger G. (2004) Instrumental insemination of Apis mellifera queens with hetero- and conspecific spermatozoa results in different sperm survival, Apidologie 35, 503-511.

Piulachs M.D., Guidugli K.R., Barchuk A.R., Cruz J., Simoes Z.L.P., Bellés X. (2003) The vitellogenin of the honey bee, Apis mellifera: structural analysis of the cDNA and expression studies, Insect Biochem. Mol. Biol. 33, 459-465.

Pontoh J., Low N.H. (2002) Purification and characterization of beta-glucosidase from honey bees (Apis mellifera), Insect Biochem. Mol. Biol. 32, 679-690.

Radloff S.E., Hepburn H.R., Koeniger G. (2003) Comparison of flight design of Asian honeybee drones, Apidologie 34, 353-358.

Reinhardt E. (1960) Kernverhältnisse, Eisystem und Entwicklungsweise von Drohnen- und Arbeiterinneneiern der Honigbiene (Apis mellifera), Zool. Jahrb. Abt. Anat. Ontog. Tiere 78, 167-234.

Rembold H. (1987) Caste differentiation of the honey bee - fourteen years of biochemical research at Martinsried, in: Eder J., Rembold N. (Eds.), Chemistry and biology of social insects, Verlag J. Peperny, München, pp. 3-13.

Rhein W. v. (1951) Über die Ernährung der Drohnenmaden, Z. Bienenforsch. 1, 63-66.

Rinderknecht H., Geokas M.C., Silverman P., Haverback B.J. (1968) A new ultrasensitive method for the determination of proteolytic activity, Clin. Chim. Acta 21, 197-203.

Roberts S.P., Harrison J.F. (1999) Mechanisms of thermal stability during flight in the honeybee Apis mellifera, J. Exp. Biol. 202, 1523-1533.

Robinson G.E. (1992) Regulation of division-of-labor in insect societies, Annu. Rev. Entomol. 37, 637665.

Robinson G.E. (2002) Genomics and integrative analyses of division of labor in honeybee colonies, Am. Nat. 160, S160-S172.

Rortais A., Arnold G., Halm M.P., Touffet-Briens F. (2005) Modes of honeybees exposure to systemic insecticides: estimated amounts of contaminated pollen and nectar consumed by different categories of bees, Apidologie 36, 71-83.

Rothe U., Nachtigall W. (1989) Flight of the honey bee. IV. Respiratory quotients and metabolic rates during sitting, walking and flying, J. Comp. Physiol. 158B, 739-749.
Ruttner F., Ruttner H. (1972) Untersuchungen über die Flugaktivität und das Paarungsverhalten der Drohnen, Apidologie 3, 203-232.

Rutz W., Lüscher M. (1974) The occurrence of vitellogenin in workers and queens of Apis mellifica and the possibility of its transmission to the queen, J. Insect Physiol. 20, 897-909.

Sacktor B. (1970) Regulation of intermediary metabolism, with special reference to the control mechanisms in insect flight muscle, Adv. Insect Physiol. 7, 267-347.

Schatton-Gadelmayer K., Engels W. (1988) Hymolymph proteins and body weight in newly emerged worker honey bees according to different rates of parasitation by brood mites (Hymenoptera: Apidae: Apis mellifera / Acarina: Varroidae: Varroa jacobsoni), Entomol. Gen. 14, 93-101.

Schlüns H., Schlüns E.A., van Praagh J., Moritz R.F.A. (2003) Sperm numbers in drone honeybees (Apis mellifera) depend on body size, Apidologie 34 577-584.

Schlüns H., Koeniger G., Koeniger N., Moritz R.F.A. (2004) Sperm utilization pattern in the honeybee (Apis mellifera), Behav. Ecol. Sociobiol. 56, 458463.

Schmickl T., Crailsheim K. (2002) How honeybees (Apis mellifera L.) change their broodcare behaviour in response to non-foraging conditions and poor pollen conditions, Behav. Ecol. Sociobiol. $51,415-425$.

Schmickl T., Crailsheim K. (2004) Inner nest homeostasis in a changing environment with special emphasis on honey bee brood nursing and pollen supply, Apidologie 35, 249-263.

Schneider P., Drescher W. (1987) The influence of Varroa jacobsoni Oud. on weight, development of weight and hypopharyngeal glands, and longevity of Apis mellifera L., Apidologie 18, 101-110.

Schreiner T. (1952) Über den Nahrungstransport im Darm der Honigbiene, Z. Vgl. Physiol. 34, 278 298.

Seidl R. (1980) Die Sehfelder und Ommatidien-Divergenzen der drei Kasten der Honigbiene (Apis mellifera), Verh. Dtsch. Zool. Ges. 73, 367.

Seeley T.D. (1982) Adaptive significance of the age polyethism schedule in honeybee colonies, Behav. Ecol. Sociobiol. 11, 287-293.

Seeley T.D. (1985) Honeybee Ecology. Princeton University Press, Princeton, New Jersey, p. 201.

Seeley T.D. (1995) The wisdom of the hive. Harvard University Press, London, England, p. 295.

Seeley T.D. (2002) The effect of drone comb on a honey bee colony's production of honey, Apidologie 33, 75-86.

Simpson J. (1955) The significance of the presence of pollen in the food of worker larvae of the honeybee, Q. J. Microsc. Sci. 96, 117-120.

Simpson J., Riedel I.B.M., Wilding N. (1968) Invertase in the hypopharyngeal glands of the honeybee, J. Apic. Res. 7, 29-36. 
Sinitzky N., Lewtschenko I. (1971) Der Gehalt an Eiweiß und freien Aminosäuren in der Hämolymphe der Arbeitsindividuen der Honigbiene, 23rd Int. Apic. Apimondia Congr., Moskau, pp. 361367.

Snodgrass R.E. (1956) Anatomy of the honey bee, Cornell University Press, London, p. 334.

Stabe H.A. (1930) The rate of growth of worker, drone and queen larvae of the honeybee, Apis mellifera Linn., J. Econ. Entomol. 23, 447-453.

Stabentheiner A., Crailsheim K. (1999) The effect of activity level and ambient temperature on thermoregulation in isolated honeybees (Hymenoptera: Apidae), Entomol. Gen. 24, 13-21.

Stabentheiner A., Kovac H. (2002) Contribution of worker bees of different age to active heat production in the brood nest of honeybee colonies, Apidologie 33, 499-500.

Stabentheiner A., Vollmann J., Kovac H., Crailsheim K. (2003) Oxygen consumption and body temperature of active and resting honeybees, J. Insect Physiol. 49, 881-889.

Straus J. (1911) Die chemische Zusammensetzung der Arbeitsbienen und Drohnen während ihrer verschiedenen Entwicklungsstadien, Z. Biol. 56, 347-397.

Suarez R.K., Staples J.F., Lighton J.R.B. (1999) Turnover rates of mitochondrial respiratory chain enzymes in flying honeybees (Apis mellifera), J. Exp. Zool. 284, 1-6.

Suarez R.K., Staples J.F., Lighton J.R.B., MathieuCostello O. (2000) Mitochondrial function in flying honeybees (Apis mellifera): respiratory chain enzymes and electron flow from complex III to oxygen, J. Exp. Biol. 203, 905-911.

Surholt B., Greive H., Hommel C., Bertsch A. (1988) Fuel uptake, storage and use in male bumble bees Bombus terrestris L., J. Comp. Physiol. 158B, 263-269.

Sutter G.R., Rothenbuhler W.C., Raun E.S. (1968) Resistance to American foulbrood in honey bees. VII. Growth of resistant and susceptible larvae, J. Invertebr. Pathol. 12, 25-28.

Szolderits M.J., Crailsheim K. (1993) A comparison of pollen consumption and digestion in honeybee (Apis mellifera carnica) drones and workers, J. Insect Physiol. 39, 877-881.

Takenaka T., Ito H., Yatsunami K., Echigo T. (1990) Changes of glucose oxidase activity and amount of gluconic acid formation in the hypopharyngeal glands during the lifespan of honey bee workers (Apis mellifera L.), Agric. Biol. Chem. 54, 21332134.
Tarpy D.R., Page R.E. (2002) Sex determination and the evolution of polyandry in honey bees (Apis mellifera), Behav. Ecol. Sociobiol. 52, 143-150.

Thrasyvoulou A., Benton A. (1982) Rates of growth of honeybee larvae, J. Apic. Res. 21, 189-192.

Tozetto S. de Oliveira, Rachinsky A., Engels W. (1995) Reactivation of juvenile hormone synthesis in adult drones of the honey bee, Apis mellifera carnica, Experientia 51, 945-946.

Tozetto S. de Oliveira, Rachinsky A., Engels W. (1997) Juvenile hormone promotes flight activity in drones (Apis mellifera carnica), Apidologie 28, 77-84.

Trenczek T., Engels W. (1986) Occurrence of vitellogenin in drone honeybees (Apis mellifica), Int. J. Invertebr. Reprod. Dev. 10, 307-311.

Trenczek T., Zillikens A., Engels W. (1989) Developmental patterns of vitellogenin haemolymph titre and rate of synthesis in adult drone honey bees (Apis mellifera), J. Insect Physiol. 35, 475-481.

Tsacopoulos M., Veuthey A.-L., Saravelos S.G., Perrottet P., Tsoupras G. (1994) Glial cells transform glucose to alanine, which fuels the neurons in the honeybee retina, J. Neurosci. 14, 1339-1351.

Van Laere O. (1971) Physiology of the honeybee corpora allata: I. Studies on queens, drones and workers kept in natural conditions, J. Apic. Res. 10, 119-124.

Wang D.I. (1965) Growth rates of young queen and worker honeybee larvae, J. Apic. Res. 4, 3-5.

Wakonigg G., Eveleigh L., Arnold G., Crailsheim K. (2000) Cuticular hydrocarbon profiles reveal agerelated changes in honey bee drones (Apis mellifera carnica), J. Apic. Res. 39, 137-141.

Weinberg K.P., Madel G. (1985) The influence of the mite Varroa jacobsoni Oud. on the protein concentration and the haemolymph volume of the brood of worker bees and drones of the honey bee Apis mellifera L., Apidologie 16, 421-436.

Winston M.L. (1987) The biology of the honey bee, Harvard University Press, Cambridge, Massachusetts, London, England, p. 281.

Woodring J., Boulden M., Das S., Gäde G. (1993) Studies on blood sugar homeostasis in the honeybee (Apis mellifera, L.), J. Insect Physiol. 39, 8997.

Woyke J., Ruttner F. (1958) An anatomical study of the mating process in the honeybee, Bee World 39, 3-18.

Wyatt G.R. (1961) The biochemistry of insect hemolymph, Annu. Rev. Entomol. 6, 75-102.

Wyatt G.R. (1967) The biochemistry of sugars and polysaccharides in insects, Adv. Insect Physiol. 4, 287-360. 